\title{
Post-mortem volatiles of vertebrate tissue
}

\author{
Sebastian Paczkowski • Stefan Schütz
}

Received: 24 May 2011 / Revised: 24 May 2011 / Accepted: 24 May 2011 / Published online: 1 July 2011

(C) The Author(s) 2011. This article is published with open access at Springerlink.com

\begin{abstract}
Volatile emission during vertebrate decay is a complex process that is understood incompletely. It depends on many factors. The main factor is the metabolism of the microbial species present inside and on the vertebrate. In this review, we combine the results from studies on volatile organic compounds (VOCs) detected during this decay process and those on the biochemical formation of VOCs in order to improve our understanding of the decay process. Micro-organisms are the main producers of VOCs, which are by- or end-products of microbial metabolism. Many microbes are already present inside and on a vertebrate, and these can initiate microbial decay. In addition, microorganisms from the environment colonize the cadaver. The composition of microbial communities is complex, and communities of different species interact with each other in succession. In comparison to the complexity of the decay process, the resulting volatile pattern does show some consistency. Therefore, the possibility of an existence of a time-dependent core volatile pattern, which could be used for applications in areas such as forensics or food science, is discussed. Possible microbial interactions that might alter the process of decay are highlighted.
\end{abstract}

Keywords Post-mortem decay. Post-mortem volatiles . Decaying vertebrates $\cdot$ Volatile emission $\cdot$ Biochemical volatile formation - Volatiles of microbial metabolism

\footnotetext{
S. Paczkowski $(\square) \cdot$ S. Schütz

Department of Forest Zoology and Forest Conservation, Büsgeninstitut, Georg August University,

Büsgenweg 3,

37077 Göttingen, Germany

e-mail: spaczko@gwdg.de
}

\section{Introduction}

A vertebrate is a complex structure of chemically interacting compounds. Some functional features like muscle contraction are constant in all vertebrates. Phospholipids in cell membranes, actin and myosin in muscle cells, or collagen and hydroxyapatite in bones are chemical structures that are indispensible in the biology of a vertebrate and exist in all vertebrates. The genetic makeup and diet have an impact on the quantitative chemical composition of a vertebrate. In muscle proteins, the relationship of different amino acids varies between species (Branscheid et al. 2007) and the quantitative composition of bones is influenced by both the diet (Sos et al. 1961) and species (Ravaglioli et al. 1996). The fat content, such as the composition and abundance of fatty acids, triglycerides, phospholipids, and steroids, shows high variability (Gurr 1988), and it is influenced by genetic makeup (Branscheid et al. 2007;Estevez et al. 2003; Insausti et al. 2005; Sink 1979a). The fat composition of the diet also directly influences the vertebrate's fat composition (Lee et al. 2004; Sink 1979b). These results indicate that vertebrates contain chemical structures of low and high variability.

Consumers or destruents are heterotrophic organisms in the food chain that are able to feed on cadavers. Consumers are adapted to hunt vertebrate prey but can also feed on cadavers and, besides other sources, destruents can feed on dead vertebrates as well. A dead vertebrate has a complex and time-dependent faunal succession composed of birds (Moreno-Opo et al. 2010), omnivorous mammals (Haglund 1997), and insects (Amendt et al. 2004;Smith 1986). There exist very little experimental literature on the microbiological succession on dead vertebrates (Hopkins et al. 2000). Microorganisms are present in all the geographical regions of the world and play the important role of recyclers in ecosystems. They degrade organic matter to inorganic substances, which 
are then made available to primary producers. The chemical reactions catalyzed by microbial enzymes yield volatile organic compounds (VOCs) as the by- or end-products. Micro-organisms can adapt their metabolism to their habitat. This adaption depends on many factors such as the complex and variable chemical composition of the decomposing dead vertebrate, temperature of the habitat, or competition between different microbial species (Kai et al. 2009). Consequently, the pattern of volatiles released during vertebrate decay can vary. The aim of this review is to summarize the volatiles whose presence has been consistently reported during the process of decay and to link these volatiles to their processes of formation. Based on the results, we discuss possible applications of these volatile patterns to forensics and the detection of food spoilage.

\section{Post-mortem decay initiated by endogenous enzymes}

Immediately after death, the heart activity ceases and the lack of oxygen leads to considerable physiological changes. Glycogen is degraded to lactic acid in the skeletal muscle (Branscheid et al. 2007). This decreases the $\mathrm{pH}$ during the first hours post-mortem. In the case of high muscle activity before death, this effect can occur even minutes after death because the muscle already lacks oxygen. Another consequence is the cessation of pyruvate transport across the mitochondrial membrane. The oxidation of pyruvate to acetyl-CoA stops, and acetyl-CoA cannot enter the citrate cycle. The respiratory chain requires the low electronegativity of oxygen because it generates the electron gradient necessary for ATP production. As ATP is a universal energy source in vertebrate cells, the termination of its anabolism leads to the cessation of regular metabolism. One of the consequences of low ATP levels is the binding of the myosin-actin complex in the muscle, resulting in rigor mortis. Another effect is the inability of the cells to repair their own membranes. Consequently, lysosomal hydrolytic enzymes are released in an uncontrolled fashion in vertebrate cells (Ito et al. 1991a, b). The proteolytic enzymes released include lysosomal cathepsins and calcium-dependent endopeptidases in the muscle cells. Endopeptidases mainly consist of calpain I for low calcium levels shortly after death and calpain II for high calcium levels. High calcium levels result from increasing influx due to the onset of decay of longitudinal tubuli in the muscle cells. These proteolytic enzymes fragment the myofibrils of muscle cells along the z-disk. They react with troponins $\mathrm{T}$ and $\mathrm{I}$, tropomyosin, C-protein, filamin, vinculin, desmin, titin, and nebulin (Dransfield 1992; Goll et al. 1983; Koohmaraie 1992, 1994). Toldra (1998) reported lipase and phospholipase activity inside fermented ham, although halophilic microorganisms were only abundant on the surface. This suggested that the activity of lipolytic enzymes arose from the muscle tissue itself. Furthermore, lipoprotein lipase is present in the skeletal muscles of rats and hydrolyses di- and triglycerides of low-density lipoproteins at an optimum $\mathrm{pH}$ value of 8 to 9 (Miller et al. 1987; Motilva et al. 1993; Okuda 1991). Lysosomal acid lipase was found in the human liver, placenta, aorta, and leukocytes (Sando and Rosenbaum 1985), and it hydrolyses lipids at a pH optimum of 4 to 5 (Motilva et al. 1993; Negre et al. 1985). This suggests that the activity of lipoprotein lipase ceases shortly after death due to lactic acid accumulation. The low $\mathrm{pH}$ suppresses lipoprotein lipase and supports the activity of lysosomal acid lipase. The phospholipids of the cell membranes are degraded by phospholipases (Toldra 1998). Autolysis of arachidonic acid by the skin enzyme system of ayu fish (Plecoglossus altivelis) yields 2-octenal, 1-octen-3-ol, 2nonenal, 2-octen-1-ol, and 3-nonen-1-ol, and the autolysis of eicopentaenoic acid yields 1,5-octadien-3-ol, 2,6-nonadienal, 2,5-octadien-1-ol, and 3,6-nonadien-1-ol (Zhang et al. 1992). In an anaerobic environment, fatty acids can remain in adipoceres in certain circumstances. Several studies have examined adipocere formation under artificial (Forbes et al. 2005a, b, c; Yan et al. 2001) and field (Forbes et al. 2002; Gill-King 1999) conditions.

In general, lysosomal hydrolytic enzymes are active at an optimum temperature of $37^{\circ} \mathrm{C}$ (Dutson 1983). Most of these enzymes are also active at lower temperatures but have lower activity. For example, some cathepsins are active at $25{ }^{\circ} \mathrm{C}$, and $\mathrm{Ca}^{2+}$-dependent proteinase $(\mathrm{CAF})$ is responsible for proteolysis in meat stored at $0-4{ }^{\circ} \mathrm{C}$ (Goll et al. 1983). Another example is calpastatin, which inhibits calpains with $87 \%$ of the maximum rate at $25{ }^{\circ} \mathrm{C}$ and $\mathrm{pH}$ 7.5. Temperature and enzyme activity are correlated in a non-linear way (Goll et al. 1983).

Reactive oxygen species (ROS) are formed enzymatically, chemically, and photochemically. They react with lipids, amino acids, and sugars. Oxidized lipids release volatile aldehydes, alcohols, or alkenes. Oxidized methionine forms $\mathrm{H}_{2} \mathrm{~S}$, while oxidized sugars form ketones (Choe and Min 2005). Living vertebrates compensate the cleavage reactions of ROS by repair processes or quench these highly reactive molecules by antioxidant defense mechanisms (Cadenas 1989). After death, these repair mechanisms cease, and ROS product emission increases. This increase might be the first sign of a postmortem VOC pattern. During the active and advanced stages of decay, these emissions play a minor role in comparison to the volatiles produced by microbial activity.

\section{Post-mortem decay of vertebrates by micro-organisms}

The microbial decay of a vertebrate is a dynamic process that depends on a highly diverse assembly of microbial species, 
their interactions (Kai et al. 2009; Stams 1994), and the climatic conditions of the habitat. Temperature has a strong effect on the microbial species composition. For instance, psychrotrophic or mesophilic bacteria exhibit optimal growth at different temperatures and also release different volatiles (Ercolini et al. 2009). Burial (Dent et al. 2004; Vass et al. 2008) and drowning or exposition (Dekeirsschieter et al. 2009; Statheropoulos et al. 2005) influence the microbial species composition. In general, the decay of a vertebrate is a process that occurs in different stages (Amendt et al. 2004; Dekeirsschieter et al. 2009) and can lead to complete decomposition or conservation, such as mummification. In the forensic literature, the decay of a vertebrate is often described in stages. The stage approach is a useful simplification of the decaying process as it is possible to characterize every stage of decay by its typical characteristics. Using this distinction, other phenomena like the infestation of the dead vertebrate with insect larvae can be described (Smith 1986). However, Matuszewski et al. found that a decomposing vertebrate can simultaneously exhibit different stages of decomposition (Matuszewski et al. 2010a) and Carter et al. states that the stages approach is an accepted and useful simplification but that the decaying process cannot be divided in discrete subunits (Carter et al. 2007). Therefore, most of the studies on volatiles of vertebrate decay (Table 3) don't mention the stage of decay in which the volatiles occurred. Recently, alternative methods for correlating postmortem interval (pmi) and decompositional process were proposed (Michaud and Moreau 2011).

Despite their destructive functions as destruents, microorganisms play an important role in living vertebrates by supporting the latter's vital functions. The number of microorganisms in the human gut was estimated to be in excess of $10^{11}$ cells/g gut contents (Moore and Holdeman 1974). Many facultative or obligate anaerobic species such as Escherichia coli and Clostridium perfringens are present in the healthy intestine where they metabolize predigested nutrients entering from the stomach (Corry 1978). Micro-organisms can adapt their metabolism to the diet of the vertebrate. The relative amounts of ammonia emitted, fecal volatile sulfur compounds, phenol and urinary 4-methylphenol in human feces depend on the relative proportion of meat in the diet of the vertebrate (Cummings et al. 1979; Geypens et al. 1997). Intestinal micro-organisms prefer different substrates such as carbohydrates or amino acids as their nutrition source or depend on the metabolic products of other microbes (Smith and Macfarlane 1996). Various microbes are present on mucous membranes, sexual organs and the skin (Jenny 1983; Labows 1982; Straehlerpohl and Exner 1985). Yeasts and bacteria may be present ante-mortem in the lymphatic and vascular system as a result of infection or uptake during nutrition (Chang and Kollman 1989; Wells et al. 1988). After death, the micro-organisms present begin to colonize the body and disperse in an uncontrolled manner from their original location. The infestation of local tissues adjacent to the intestine and the capillaries of the lymphatic or vascular system characterize the beginning of this migration. A second important source of microbes is the mucous membrane of the respiratory system. This microbial community consists of Staphylococcus aureus, some Streptococcaceae, Neisseria catarrhalis, Corynebacterium xerosis, Coryne. pseudodiphtheriticum, the yeast species Candida albicans and many other microbial species. In guinea pigs, it was reported that the immunosystem could neutralize spreading microbes during the first $24 \mathrm{~h}$ after death (Gill et al. 1976). This led to the hypothesis that after death, ROS oxidation and autolysis dominate decay until the immunosystem fails and microbial growth increases. Of course, the number of microbes mentioned here is limited to only a few examples. For more detailed information, see Ercolini et al. (2009) and Corry (1978).

\section{Carbohydrates}

The main substrates for microbial growth offered by a vertebrate are water, carbohydrates, amino acids, fats and minerals (Dent et al. 2004). Carbohydrates are the most readily utilized nutrition source for both microbes and mammals (Boumba et al. 2008). The Embden-MeyerhofParnas (EMP) glycolytic pathway and the Entner-Doudoroff (ED) pathway yield pyruvate from glucose. Pyruvate is fermented to ethanol and acetic acid by bacteria and yeasts (Boumba et al. 2008; Gottschalk 1986). Other by-products of this fermentation are pyruvic acid, lactic acid, butanoic acid, propanoic acid, acetaldehyde, acetone, propan-1-ol, propan2-ol, butan-1-ol and butane-1,3-diol (Boumba et al. 2008; Dent et al. 2004; Waksman and Starkey 1931). Incomplete aerobic degradation of sugar monomers by fungi yields organic acids such as glucuronic acid, citric acid and oxalic acid. Complete aerobic decay of sugar monomers results in carbon dioxide and water.

Clostridiaceae are obligate anaerobic bacteria that are present in the intestine and in anaerobic soil layers. Since they sporulate and can therefore survive under aerobic conditions, these bacteria can colonize a dead vertebrate from inside and from the external environment. This family is represented by species such as Clostridium perfringens (welchii), C. litus-eburense (Corry 1978; Haagsma 1991) and C. paraputrificum (Corry 1978). Many clostridiaceae species ferment pyruvate formed from carbohydrates to acetone, ethanol, butan-1-ol, acetic acid, butanoic acid or butane-1,3-diol (Boumba et al. 2008). Enterobacteriaceae such as $E$. coli are facultative anaerobes that are present in the intestine. E. coli ferments the pyruvate formed by glycolysis by mixed acid fermentation (Table 1) to lactic acid, succinic acid, acetic acid, formic acid and ethanol 
Table 1 Products of carbohydrate-utilizing microbes in a facultative anaerobic environment

\begin{tabular}{|c|c|c|c|}
\hline Pathway & Microbial families and species & Location & Metabolic products \\
\hline \multirow[t]{6}{*}{ Mixed acid fermentation } & Enterobacteriaceae & Intestine & $\begin{array}{l}\text { Lactic acid, succinic acid, } \\
\text { acetic acid, formic acid, ethanol }\end{array}$ \\
\hline & Escherichia coli & & \\
\hline & Enterococcaceae & $\begin{array}{l}\text { Oral cavity, intestine, } \\
\text { urethra, sexual organs }\end{array}$ & $\begin{array}{l}\text { Lactic acid, succinic acid, } \\
\text { acetic acid, formic acid, ethanol }\end{array}$ \\
\hline & $\begin{array}{l}\text { Enterococcus faecalis, } \\
\text { Enterococcus faecium }\end{array}$ & & \\
\hline & Bacillaceae & Upper soil layers & $\begin{array}{l}\text { Lactic acid, succinic acid, acetic acid, } \\
\text { formic acid, ethanol, butane-2,3-diol }\end{array}$ \\
\hline & Bacillus subtilis & & \\
\hline \multirow[t]{3}{*}{ Lactic acid fermentation } & Streptococcaceae & Oral cavity & Acetic acid, ethanol \\
\hline & Lactobacillaceae & Intestine & Lactic acid, ethanol \\
\hline & Lactobacillus acidophilus & & \\
\hline 2,3 Butanediol fermentation & $\begin{array}{l}\text { Klebsiella pneumoniae } \\
\text { subsp. pneumoniae }\end{array}$ & Intestine & $\begin{array}{l}\text { Butane-2,3-diol, lactic acid, } \\
\text { acetic acid, formic acid, ethanol }\end{array}$ \\
\hline \multirow[t]{2}{*}{ Propanoic acid fermentation } & Propionibacteriaceae & Intestine, skin & Propanoic acid, acetic acid \\
\hline & Propionibacterium acnes & & \\
\hline \multirow[t]{2}{*}{ Bifidum pathway } & Bifidobacteriaceae & Intestine, sexual organs & Lactic acid, acetic acid \\
\hline & Bifidobacterium animalis & & \\
\hline
\end{tabular}

(Boumba et al. 2008). It can switch from glycolysis to lactose utilization to form pyruvate, which is then transformed to the volatile products acetic acid and ethanol. The genus Klebsiella of the family enterobacteriaceae is a gramnegative, facultative anaerobe that lives in soil, water or grain. Klebsiella pneumoniae subsp. pneumoniae is the only species of this genus known to be abundant in the intestine of vertebrates. Among intestinal enterobacteriaceae, this species is characterized by its use of butane-2,3-diol fermentation for energy production. Butane-2,3-diol, lactic acid, acetic acid, formic acid and ethanol are the main endproducts of butane-2,3-diol fermentation (Gottschalk 1986). Staphylococcus aureus from the family Staphylococcaceae, formerly a member of Micrococcaceae, is a bacterium that is abundant in the soil, skin and respiratory system of vertebrates. Streptococcaceae are facultative anaerobes that are abundant in the oral cavity where they ferment carbohydrates to lactic acid (Table 1). The facultative anaerobic family enterococcaceae ferments carbohydrates to lactic acid by mixed acid fermentation. Members of this family such as Enterococcus faecalis and Enterococcus faecium are present in the oral cavity, intestine, urethra and sexual organs. Due to their lack cytochromes and porphyrins, these organisms are aero-tolerant. Propionibacteriaceae such as Propionibacterium acnes are aero-tolerant anaerobic species that grow relatively slowly on the skin and in the intestine of vertebrates. These bacteria can ferment carbohydrates or lactic acid to propanoic acid and acetic acid by propanoic acid fermentation (Table 1). Species of the family lactobacillaceae such as Lactobacillus acidophilus, which grows at a $\mathrm{pH}$ of 4-5 or lower, are facultative anaerobes or obligate anaerobes present in the intestine of vertebrates. They produce lactic acid (homofermentive) or lactic acid, acetate and ethanol (heterofermentive) by lactic acid fermentation. Bifidobacteriaceae such as Bifidobacterium animalis are anaerobic bacteria present in the intestine or sexual organs of vertebrates where they metabolize carbohydrates by the bifidum pathway to form lactic acid and acetic acid (Table 1). The contribution of yeasts to vertebrate decay is less than that of bacteria (Corry 1978). One yeast species reported to be present on decaying vertebrates is Candida sp., especially Candida albicans (Chang and Kollman 1989; Corry 1978), which is present in the intestine, on the mucous membranes of the oral cavity and the genitals and between fingers and toes. Saccharomyces cerevisiae (Corry 1978; Davis et al. 1972), another yeast species, is a facultative aerobe that obtains energy by respiration or fermentation.

The constant inner putrefaction caused by these microorganisms and other microbes leads to the formation of organic and inorganic gases that cause bloating. The putrefaction of the cadaver that follows results in the breakage of the outer skin. Consequently, the inner fluid comes into contact with oxygen and aerobic species from the air and soil, which then colonize it. Aerobic bacillaceae species, mainly Bacillus subtilis, which is abundant in the upper soil layers, can adapt to facultative anaerobic conditions by switching to mixed acid fermentation of sugars. This microbe grows faster under aerobic 
conditions. Pseudomonaceae are abundant in soil, water and on the skin of vertebrates. They are aerobic and cannot ferment. For energy production, they utilize the Entner-Doudoroff pathway, which yields pyruvate predominantly from hexoses. These microbes can also generate the electron gradient of the respiratory chain by reducing nitrate to nitrogen instead of reducing oxygen. Neisseriaceae such as Neisseria catarrhalis are aerobic species that are abundant on the mucosal membranes of vertebrates. Corynebacteriaceae are aerobic or facultative anaerobic bacteria, and several species such as Corynebacterium xerosis or Coryne. pseudodiphtheriticum inhabit the mucosal membranes or skin of vertebrates.
Amino acids

In all vertebrates, amino acids are the major components of muscle tissue proteins, membrane proteins and free proteins. Although the functional mechanisms of proteins are complex and diverse, they are composed of the same amino acids. Microbial proteases and peptidases yield free amino acids. Amino acid degradation can also lead to the formation of volatile products (Table 2).

Durlu-Özkaya et al. (Durlu-Özkaya et al. 2001) stated that putrescine, cadaverine, tyramine and histamine in the skeletal muscle are products of proteolytic bacterial metabolism and that $E$. coli plays an important role in the

Table 2 Metabolic products of amino acid degradation

\begin{tabular}{|c|c|c|}
\hline \multirow[t]{2}{*}{ Leucine } & Ehrlich pathway, anabolism & $\begin{array}{l}\text { Propan-1-ol, 2-methyl-propan-1-ol, } \\
\text { 2-methyl-butan-1-ol, 3-methyl-butan-1-ol }\end{array}$ \\
\hline & M. phenylpyruvica, S. xylosus, S. starnosus & $\begin{array}{l}\text { 3-Methyl-butan-1-ol, 3-methyl-butanal, } \\
\text { 3-methyl-butanoic acid }\end{array}$ \\
\hline \multirow[t]{2}{*}{ Isoleucine } & Ehrlich pathway, anabolism & $\begin{array}{l}\text { 1-Propanol, 2-methyl-propan-1-ol, } \\
\text { 2-methyl-butan-1-ol, 3-methyl-butan-1-ol }\end{array}$ \\
\hline & Yeast & $\begin{array}{l}\text { Propan-1-ol, 2-methyl-butan-1-ol, } \\
\text { 3-methyl-butan-1-ol, pentanol }\end{array}$ \\
\hline Threonine & Yeast & $\begin{array}{l}\text { 1-Propanol, 2-methyl-1-butanol, } \\
\text { 3-methyl-1-butanol, pentan-1-ol }\end{array}$ \\
\hline Arginine $>$ ornithine & Ornithine decarboxylase & Putrescine \\
\hline Lysine & Lysine decarboxylase & Cadaverine \\
\hline \multirow[t]{3}{*}{ Tyrosine } & $\begin{array}{l}\text { S. albus, B. fragilis, Fusobacterium sp., } \\
\text { Bifidobacterium spp., C. paraputrificum, } \\
\text { C. butyricum, C. sporogenes, C. septicum }\end{array}$ & 4-Methylphenol (anaerobe) \\
\hline & & $\begin{array}{l}\text { 2-Phenylethanol, phenylacetaldehyde, } \\
\text { phenylacetic acid }\end{array}$ \\
\hline & E. coli, Proteus sp., E. faecalis, S. albus & Phenol (facultative anaerobe) \\
\hline \multirow[t]{6}{*}{ Phenylalanine } & Phenylalanine decarboxylase $+\mathrm{Fe}^{3+}$ & Green complex \\
\hline & Pseudomonaceae (aerobe) & $\begin{array}{l}\text { 2-Phenylethanol, phenylacetaldehyde, } \\
\text { phenylacetic acid }\end{array}$ \\
\hline & & Phenylpropanoic acid \\
\hline & M. phenylpyruvica, S. xylosus & $\begin{array}{l}\text { Ethylbenzene, benzaldehyde, benzonitrile, } \\
\text { 2-hydroxybenzaldehyde }\end{array}$ \\
\hline & $\begin{array}{l}\text { P. putida, E. coli, K. pneumoniae, } \\
\text { B. halodurans }\end{array}$ & Ethenylbenzene, ethylbenzene \\
\hline & Denitrifying bacteria & $\begin{array}{l}\text { 1-Phenylethanol, phenylethanone, } \\
\text { benzoyl-acetate }\end{array}$ \\
\hline Tryptophan & $\begin{array}{l}\text { Bacteroides, Lactobacillus, Clostridium, } \\
\text { Bifidodobacterium, Peptostreptococcus }\end{array}$ & $\begin{array}{l}\text { Indole, indoyl acetic acid and } \\
\text { indoyl propanoic acid }\end{array}$ \\
\hline \multirow[t]{2}{*}{ Cysteine } & Anaerobe & Elemental sulfur, hydrogen sulfide \\
\hline & & $\begin{array}{l}\text { Hydrogen sulfide, dimethyl sulfide, } \\
\text { dimethyl disulfide, dimethyl trisulfide, } \\
\text { dimethyl tetrasulfide }\end{array}$ \\
\hline \multirow[t]{3}{*}{ Methionine } & & $\begin{array}{l}\text { Methanethiol, dimethyl disulfide, } \\
\text { dimethyl trisulfide }\end{array}$ \\
\hline & Aerobe & Dimethyl sulfide \\
\hline & $\begin{array}{l}\text { H. alvei, E. agglomeran, S. liquefaciens, } \\
\text { A. putrefaciens and A. hydrophila }\end{array}$ & Methanethiol, dimethyl sulfide \\
\hline
\end{tabular}


formation of histamine and cadaverine. L-Arginine hydrolysis yields ornithine, which is then decarboxylated to putrescine. Decarboxylated lysine yields cadaverine (Gill-King 1999). The amino acids valine, leucine and isoleucine are fermented to higher alcohols such as propan-1-ol, 2-methyl-propan1-ol, 2-methyl-butan-1-ol and 3-methyl-butan-1-ol by the Ehrlich pathway or in reverse as by-products of anabolic biosynthetic pathways (Boumba et al. 2008; Chen 1978; Derrick and Large 1993). Moraxella phenylpyruvica, Staphylococcus xylosus and Staphylococcus starnosus transforme degrade leucine to 3-methyl-butan-1-ol, 3-methyl-butanal and 3-methylbutanoic acid (Moller et al. 1998; Stahnke 1999). 4-Methylphenol and propanoic acid phenylester are products of anaerobic tyrosine catabolism by Staphylococcus albus, Bacteroides fragilis, Fusobacterium sp., Bifidobacterium spp., Clostridium paraputrificum, C. butyricum, C. sporogenes and $C$. septicum. Tyrosine degradation also yields 2-phenylethanol, phenylacetaldehyde and phenylacetic acid (Smith and Macfarlane 1996). E. coli, Proteus sp., Enterococcus faecalis and $S$. albus produce phenol under facultative anaerobic conditions from the same amino acid (Bone et al. 1976). Phenylalanine degradation yields 1-phenylethanol, 2-phenylethanol, phenylacetaldehyde, phenylacetic acid and phenylpropanoic acid (Luengo et al. 2001; Macfarlane and Allison 1986; Rabus and Heider 1998; Smith and Macfarlane 1996). Tryptophan degradation by Bacteroides, Lactobacillus, Clostridium, Bifidobacterium and Peptostreptococcus yields indole, indoyl acetic acid and indoyl propanoic acid (Smith and Macfarlane 1996). L-Phenylalanine can form greenish products in the presence of phenylalanine deaminase and ferric ions $\left(\mathrm{Fe}^{3+}\right)$ (Gill-King 1999). Ferric ions are present in the soil and hemoglobin. Hemolytic Streptococcaceae can degrade hemoglobin, leading to the accumulation of greenish products in the dead vertebrate. Under aerobic conditions, indolic and phenolic compounds are oxidized by mono- and dioxygenases (Young and Rivera 1985). Under anaerobic conditions, these are fermented by methanogenic bacteria present in the large intestine to phenol, cyclohexanol, cyclohexanone, hexanoic acid, hexanedioic acid, butanoic acid, propanoic acid, acetic acid, $\mathrm{CO}_{2}, \mathrm{H}_{2}$ and methane (Young and Rivera 1985). Under aerobic conditions, Coccaceae, Pseudomonaceae, Bacteriaceae, Bacillaeceae, Candida $s p$, Saccharomyces $s p$ and certain higher fungi form pyruvate, acetyl-CoA and succinate. Possible byproducts are quinoline, glutamate, 2-butendioic acid, 2oxopropanoic acid and acetic acid (Evans 1963). Yeasts can degrade the amino acids threonine, leucine, isoleucine and valine to 1-propanol, 2-methyl-butan-1-ol, 3-methyl-butan-1ol and pentan-1-ol (Boumba et al. 2008).

Sulfur compounds are prominent VOCs emitted by decaying vertebrates (Stensmyr et al. 2002). The sulfur-containing amino acids cysteine and methionine play an important role in the formation of volatile sulfur compounds such as hydrogen sulfide, dimethyl sulfide, dimethyl disulfide, dimethyl trisulfide, dimethyl tetrasulfide and thiols (Dent et al. 2004; Freney 1967; Gill-King 1999; Kadota and Ishida 1972). The facultative anaerobic Proteus species from intestine, soil, and water releases hydrogen sulfide. Dimethyl sulfide is a product of methionine decomposition under aerobic conditions. Cysteine degradation can yield elemental sulfur under anaerobic conditions (Freney 1967). Methanethiol is a product of methionine degradation (Frederick et al. 1957; Kadota and Ishida 1972; Wolle et al. 2006), and it can lead to the formation of dimethyl disulfide during GC analysis (Lestremau et al. 2004). This oxidative dimerisation may also occur during the proteolysis of vertebrates (Frederick et al. 1957). Methanethiol and dimethyl sulfide (Lindinger et al. 1998) were found to be by-products of the metabolism of Hafnia alvei, Enterobacter agglomeran, Serratia liquefaciens, Alteromonas putrefaciens and Aeromonas hydrophila (Dainty et al. 1989). The amount of sulfur compounds emitted by bacteria is species-dependent (Stutz et al. 1991). Under aerobic conditions, some bacteria, such as those from the thiobacillus group, can transform sulfides to sulfurous acids, elemental sulfur, and sulfate (Dent et al. 2004). The formation of secondary products from sulfur compounds under natural and artificial conditions is an indicator of the reactivity of these compounds (Lestremau et al. 2004).

The variability of biogenic amines is high and depends on the micro-organisms growing on the tissue (Ansorena et al. 2002). Dimethylamine (Lindinger et al. 1998) or trimethylamine is formed by the oxidative decarboxylation of free amino acids by Sherwanella putrefaciens (Dainty et al. 1989; Lopez-Caballero et al. 2001). As these amines are not volatile under moderate temperature conditions, further degradation is necessary for the production of VOCs. In general, these compounds are further degraded to ammonia, oxidized to nitrite by Nitrosomonas spp. and further to nitrate by Nitrobacter spp. in the soil under aerobic conditions (Waksman and Starkey 1931). Aerobic Pseudomonaceae are proteolytic bacteria that use proline, glutamate, lysine or Lphenylalanine as their $\mathrm{C}$ and $\mathrm{N}$ sources (Herrera et al. 2010).

Facultative or obligate aerobic Bacillaceae excrete the non-specific proteolytic enzyme subtilisin (Higgins and Burns 1975). Micrococcaceae such as Micrococcus luteus are aerobic and abundant in the soil and surface water and are also present on the skin of vertebrates. The proteolytic species Serratia proteamaculans, Pseudomonas fragi and Carnobacterium maltaromaticum were detected on beef (Ercolini et al. 2009). Other micro-organisms reported to grow on muscle tissue are the facultative anaerobe Brochotrix thermosphacta and the facultative anaerobe and aero-tolerant Leuconostoc mesenteroides, Leuc. curvatus, Pseudomonas lundensis and Pseudomonas fluorescens biovar. Moraxella species were also identified (Dainty et al. 1985; Stutz et al. 1991; Vanderzant et al. 1986). These 
species are generally abundant in the respiratory tract (Molin and Ternstrom 1986).

\section{Lipids}

In vertebrates, all cells contain fat in their phospholipid membranes. Fatty acids such as linoleic acid or arachidonic acid are typically present in abundance in lipid membranes (Frankel 1983). Intramuscular fat consists of fat cells inside the muscular tissue (Gandemer 2002), and depot fat is the fat under the skin. Intramuscular fat and depot fat contain triglycerides. The hydrolysis of triglycerides by microbial lipolytic enzymes yields glycerol and fatty acids.

Glycerol degradation results in the formation of pyruvate, ATP and NADH. Pyruvate degradation yields products such as butan-1-ol, butanoic acid, acetone, ethanol, propionic acid, acetic acid, formic acid, lactic acid, propane-1,3-diol, propane-1,2-diol and butane-2,3-diol (Boumba et al. 2008). Many Clostridiaceae are obligate anaerobic species that ferment pyruvate to acetone, ethanol, butan-1-ol, acetic acid, butanoic acid or butane-1,3-diol. E. coli catabolizes glycerol to propanol and propanoic acid (Boumba et al. 2008).

The fatty acids of vertebrates are further oxidized or hydrogenised (Dent et al. 2004) to several volatile compounds. However, there is a lack of detailed studies on volatile formation by microbial fatty acid degradation (Combet et al. 2006; Kionka and Kunau 1985). Although the beta-oxidation enzymes of prokaryotes, fungi, and plants differ from each other (Heath et al. 2002; Kionka and Kunau 1985), their catabolic activity is comparable and yields acetyl-CoA or propionyl-CoA (Gottschalk 1986). AcetylCoA is degraded to either ethanol, acetic acid, acetaldehyde, and acetone or to propan-1-ol, propan-2-ol, and propionic acid (Boumba et al. 2008). The volatile by-products of lipoxygenase activity in fungi are mainly C6 or C9 aldehydes and $\mathrm{C} 8$ alcohols or $\mathrm{C} 8$ ketones (Combet et al. 2006; Feussner et al. 1997).

Aerobic oxidation of linoleic acid yields 2,4-decadienal, 3nonenal, hexanal, 2,4,7-decatrienal, 2,6-nonadienal, 3-hexenal, and propanal. Further chemical groups include ketones, hydrocarbons, acids, and epoxides. C. perfringens (welchii) (Polson et al. 1985) or other species from the genera Pseudomonas, Acinetobacter, and Bacillus (Gottschalk 1986) are lipolytic and yield volatile aldehydes, ketones, or esters (Boumba et al. 2008; Dent et al. 2004). Oxidation of linoleic acid in fungi yields the eight-carbon volatiles 1-octen3-ol, octan-3-ol, octan-1-ol, 1-octen-3-one, and octan-3-one (Combet et al. 2006). Tetradecanoic acid, hexadecanoic acid, octadecanoic acid, 9-octadecenoic acid, 10hydroxyoctadecanoic acid, and $(Z, Z)-9,12$-octadecadienoic acid are part of the adipocere. The latter can form in the later stages of decay by saponification of fatty acids under anaerobic conditions, neutral or slightly alkaline $\mathrm{pH}$, and in the presence of certain enzymes (Forbes et al. 2002, 2005a, b, c; Gill-King 1999; Notter et al. 2009).

Bones

Bones consist of organic and mineral components. The organic components are mainly fat and proteins. In ancient bones, it is possible to detect triglycerides, free fatty acids, collagen, amino acids, and non-collagenous proteins such as osteocalcin and haemoglobins (Evershed et al. 1995; Schultz 2006; Vanklinken et al. 1994; Vanklinken and Hedges 1992). Therefore, fat degradation can lead to the release of volatiles in the later stages of decay. Fat is the major component of marrow consisting of different saturated and unsaturated fatty acids, omega- 6 polyunsaturated fatty acid (PUFA), and omega-3 PUFA (Yeung et al. 2008). Vass et al. investigated the volatile emissions of exposed mammalian bones. They found different ratios of ketones, aldehydes, and alcohols in the four different mammalian species, and among other compounds they identified nonan-2-one, nonanal, hexanal, and hexan-1-ol (Vass et al. 2008). Ketones and aldehydes are products of fat degradation (Boumba et al. 2008; Dent et al. 2004). Alcohols, especially hexan-1-ol and 1-octen-3-ol, are by-products of fungal metabolism (Borjesson et al. 1993; Korpi et al. 1998; Larsen and Frisvad 1995; Pasanen et al. 1996; Sunesson et al. 1996; Thakeow et al. 2008), and signs of fungal activity are present on bones (Marinho et al. 2006). ROS might also play a role in the formation of volatiles from bones (Choe and Min 2005). Of the total bone proteins, $90 \%$ to $95 \%$ consist of different collagen proteins. These are degraded to peptides by bacterial collagenases (Macfarlane and Allison 1986). Streptomyces spp. are aerobic bacteria living in the soil, and they can cleave the strong disulfide bonds in the collagen molecule (Gray and Williams 1971). The mineral component of bones consists of hydroxyapatite, which is degraded by physical weathering.

\section{Microbial interactions}

Micro-organisms can show ecological interactions such as mutualism or competition. These interactions affect the pattern of volatiles released by the decaying vertebrate. Smith et al. investigated the formation of phenolic and indolic compounds by intestinal microbes in feces under anaerobic conditions and found variations in the relative quantity of phenolic and indolic volatiles, depending on the microbial density (Smith and Macfarlane 1996). Therefore, microbial density seems to influence their metabolic pathways due to inter- and intraspecific interactions. An example of mutualism is the fermentation of ethanol to acetate and $\mathrm{H}_{2}$. As the $\mathrm{H}_{2}$ concentration increases, the growth of the ethanol- 
fermenting microbes decreases. The presence of microbes that utilize $\mathrm{H}_{2}$ to reduce $\mathrm{CO}_{2}$ to methane increases the growth rate of the first micro-organism (Bryant et al. 1967). The suppression of microbial ethanol fermentation in the presence of hydrogen-utilizing micro-organisms is an example of the competition between microbes (Iannotti et al. 1973). The lower partial pressure of $\mathrm{H}_{2}$ leads to its formation from NADH by ethanol-fermenting microbes instead of coupling of the oxidation of NADH to the reduction of acetyl-CoA to ethanol. Both mechanisms may be important for post-mortem ethanol detection. The mycelial growth and spore germination of fungi are inhibited by $P$. fluorescens and other Pseudomonaceae (Fernando et al. 2005). Dimethyl trisulfide is one of the inhibitory substances utilized by the bacteria in this competitive interaction. Phenol is an antiseptic substance emitted by proteolytic Bacillaceae ( $\mathrm{Gu}$ et al. 2007), E. coli, Proteus sp., Enterococcus faecalis and S. albus (Bone et al. 1976), and it might constrain the growth of other microbes. Trichosporon cutaneum can degrade phenol, but the presence of cresols such as 4-methylphenol delays this reaction (Alexieva et al. 2008). 4-Methylphenol is a metabolic product of $S$. albus, B. fragilis, Fusobacterium sp., Bifidobacterium spp., C. paraputrificum, C. butyricum, C. sporogenes, and C. septicum. All these data suggest a complex interaction based on phenolic compounds. The lipid metabolism of microbes yields fatty acids that show an antimicrobial effect (Jay 2000). In particular, the emission of aldehydes increases during the later stages of decay (Dekeirsschieter et al. 2009; Vass et al. 2008). This might lead to the conclusion that fatty acids are prominently decomposed in the later stages of decay to form aldehydes and that interactions based on fatty acids might occur during these stages. Volatiles emitted by the environment can also influence microbial growth on decaying vertebrates (Gilbert et al. 1969). For instance, thiols and sulfides were found to stimulate (King and Coley-Smith 1969) or suppress fungal growth (Lewis and Papavizas 1972). These results show the complexity of microbial interactions, which affect the VOCs emitted.

\section{Post-mortem volatiles}

The results of volatile analysis are influenced by abiotic factors, sampling technique, and analytical setup. Abiotic factors directly influence the release of volatiles from a vertebrate. As mentioned above, the temperature influences the activity of volatile-generating enzymes and the microbial species composition. Moisture also affects the process.

The compounds identified by volatile analysis depend on the sampling technique and the analytical setup. The sampling technique can be passive, for instance, in a closed container, or active with a constant gas flow. Depending on the exposed adsorbent, the compounds enrich according to their chemical properties. A non-specific material adsorbs many different volatiles, whereas a specific material is selective for characteristics such as polarity or certain functional groups. As an example, the SPME (Solid Phase Micro Extraction) technique was developed for uncomplicated and fast volatile sampling in a static headspace. A short fiber covered with an adsorption material is exposed to the headspace of the sample. After equilibration between the solid and the gaseous phase, the fiber is directly inserted in the injector of a GC system and the volatiles are thermally desorbed for analysis. The surface of the SPME fibers is modified to adsorb different classes of volatiles. For instance, polydimethylsiloxane (PDMS)-covered fibers adsorb predominantly non-polar compounds or Carbowaxcovered fibers adsorb predominantly polar compounds. There exist several surface adsorbents, which can be combined with each other in order to achieve selectivity or non-selectivity during sampling. Some fiber types used in analytical studies are listed in Table 4. The exposure time of the fiber is important as well because a short exposure time favors the adsorption of compounds with a high volatility, while discriminating compounds with a low volatility. A long exposure will lead to desorption of highly volatile compounds, while additional low-volatility compounds are adsorbed. Moreover, individual adsorption properties may vary between fibers from different lots. Therefore, quantification with the SPME technique requires an internal standard with known quantity. SPME can be used for the extraction of compounds from liquid solutions (Ercolini et al. 2009). The liquid extracts can be esterified to enhance the trace analysis (Forbes et al. 2002, 2005a, b, c). For more information on SPME sampling, see Tholl et al. (2006). Dynamic headspace sampling techniques are used to find volatiles with low emission rates. A continuous air stream is led through an adsorbent to trap the volatiles out of the sampling system. Either the air is circulated in the sampling system or filtered air enters the system, is enriched with volatiles from the sample, and led through the adsorbent and then out of the system. For dynamic headspace sampling, different adsorbents can be used. Tubes filled with different selective or unselective adsorbent powders, for instance, TENAX, Carbotrap, Carbotrap C, and Carbosieve S-III, are commercially available. For increasing performance, a tube can be filled with different adsorbent powders. Vass et al. used triple-sorbent traps for their analysis of buried human remains (Vass et al. 2004, 2008). Another possibility is the trapping of the volatiles by directing the gas flow through cooled liquid solvents such as cyclohexane, methanol, or dichloromethane. Tholl et al. (2006) give a more detailed description of volatile sampling techniques (Tholl et al. 2006).

Any chemical analysis of the adsorbed volatile compounds has its own analytical window that enables the 
identification of certain volatiles while excluding others. For instance, the polarity of a compound influences its retention on a GC column. A low molecular weight polar compound might only be detectable by high retention on a polar column and might be undetectable because of lower retention on a non-polar column. Furthermore, the detection of stereo isomers requires enantiomer-selective columns with modified surfaces (Dotterl et al. 2006). The identification of isotope ratios, like ${ }^{13} \mathrm{C} /{ }^{12} \mathrm{C}$ or ${ }^{15} \mathrm{~N} /{ }^{14} \mathrm{~N}$, requires a modified GC setup (Boschker and Middelburg 2002; Meier-Augenstein 2002). Both techniques can be used to specify trace analytical results. Especially, the identification of isotope ratios in cadaveric volatile compounds can give important information on the nutrition of the dead vertebrate or the microbial communities growing on it (Boschker and Middelburg 2002; Meier-Augenstein 2002).

Finally, the detector attached to the column determines the information collected on the substances. A flame ionization detector (FID) gives information about the retention time and the peak area of compounds in a sample. Identification and quantification can only be achieved by using standard compound samples with known concentration. However, the selection of standard compounds is problematic when the compound to be identified is unknown. A mass spectrometer (MS) is able to identify compounds not only by the retention time of standard compounds but also by comparing the fragment pattern of a compound in a sample with a fragment pattern database. However, a standard compound sample has to be used for exact identification as well because the fragment pattern database is restricted to some thousand compounds and several compounds have the same fragment pattern. For quantification, a reference quantity is necessary as well. The selection of possible standard compounds is much easier with a MS system than with a FID because the database gives a pre-selection of possible candidates. However, a false identification is still possible when two compounds have very similar mass spectra and the same retention time. In order to improve the trace analysis, it is possible to use two-dimensional gas chromatography ( $\mathrm{GC} \times$ GC). Two columns with different polarity are coupled to each other and, as a result, every compound has two retention indices. Two compounds, which have the same retention time on a non-polar column, might have a different retention time on the second polar column in a two-dimensional GC. Another approach to enhance compound identification is the time of flight MS (TOFMS). This detector measures the fragment-specific flight time from the point of fragmentation to the detector plate. TOFMS analysis allows a more precise differentiation between atomic masses in comparison to conventional mass spectrometers. The studies listed in Table 4 use GC/ MS analysis; only Kalinova et al. is an exception due to using GC $\times$ GC-TOFMS (Kalinova et al. 2009). Hübschmann et al. give further information on gas chromatography and coupled detector systems (Hübschmann 2009). Since it is known that the analytical method influences the results, Table 4 has been provided to supplement Table 3 and list selected information on sampling, sample preparation, and sample analysis. Another factor in chemical analysis is the modification of volatile compounds during the analytical procedure. For instance, volatile sulfur compounds can be transformed during GC-MS analysis (Lestremau et al. 2004).

The analysis of post-mortem volatiles does not only depend on the analytical parameters itself. Other decomposers might influence the volatile pattern of a decaying vertebrate by feeding. Scratches or holes made by scavengers can open the dead body before it breaks up due to swelling. As a result, oxygen will infiltrate the body, favoring the growth of aerobic or facultative aerobic microbial species and suppressing that of obligate anaerobes. Aerobic (Straehlerpohl and Exner 1985) and anaerobic (Gulzow 1982) micro-organisms of the scavengers oral cavities could be introduced. Larval growth might influence the volatile pattern because proteolytic enzymes are excreted by the larvae. The cuticle hydrocarbons of these insects might also contribute to the volatile pattern. Burying beetles (Nicrophorus spp.) even bury small vertebrates and inhibit the decay with excretions from their glands (Kalinova et al. 2009).

Table 3 lists the VOCs reported in studies on the decay of vertebrate tissue. Because of the large number of reported VOCs, the list contains only those that have been identified in more than one study. The volatile compounds butane-1,2-diol, butane-1,3-diol, propane-1,3-diol, propane1,2-diol, butane-2,3-diol, propan-1-ol, and propan-2-ol are not reported in any of the reviewed experimental studies although they are known to be volatile products of amino acid degradation (Boumba et al. 2008). Table 4 contains additional information about the method used.

\section{Application of post-mortem volatiles}

Insects are important cues for criminal investigations as their larval development on corpses can help to estimate the time since death. It is not possible to determine the exact day of death as larval development is influenced by many environmental factors. Therefore, additional cues are necessary to support juristically accepted estimation of the pmi. Several authors suggested the use of insects to select volatiles, which are important in the dynamic emission pattern of vertebrate decay (LeBlanc and Logan 2010; Paczkowski et al. 2011; Statheropoulos 2005; Vass et al. 2002). These volatiles could be an additional cue for determining the time since death. However, the variation of cadaveric volatiles is very high. In order to find useful 
Table 3 VOCs identified in experimental studies and reviews. The cross-references to Table 4 contain information on the experimental conditions

\begin{tabular}{llll}
\hline Compound & $\begin{array}{l}\text { CAS } \\
\text { number }\end{array}$ & Origin & Publication \\
\end{tabular}

Alcohols

Ethanol

64-17-5

2-Methyl-propan-1-ol

$78-83-1$

Butan-1-ol

71-36-3

78-92-2

137-32-6

2-Methyl-butan-1-ol

3-Methyl-butan-1-ol

Pentan-1-ol

71-41-0

Hexan-1-ol

2-Ethyl-hexan-1-ol

Octan-1-ol

1-Octen-3-ol

Acids

Formic acid

Acetic acid

Propanoic acid
$111-87-5$

3391-86-4

64-18-6

64-19-7

111-27-3 Fungal metabolism

(Borjesson et al. 1993;

Korpi et al. 1998;

Larsen and Frisvad 1995;

Pasanen et al. 1996;

Sunesson et al. 1996;

Thakeow et al. 2008)

104-76-7

Linoleic acid

(Combet et al. 2006)

Linoleic acid

(Combet et al. 2006)

Glycerol, pyruvate

(Boumba et al. 2008)

Carbohydrates, indolic/phenolic compounds, glycerol

(Boumba et al. 2008;

Evans 1963; Smith and

Macfarlane 1996;

Young and Rivera 1985)

Amino acids

(Demeyer and Vannevel 1979)
(Gottschalk 1986; Corry 1978; O'Neal

and Poklis 1996; Stutz et al. 1991;

Dent et al. 2004; Statheropoulos et al. 2005;

Statheropoulos et al. 2007;

Boumba et al. 2008;

Dekeirsschieter et al. 2009) $2,6,7,17$

(Derrick and Large 1993;

O'Neal and Poklis 1996;

Statheropoulos et al. 2005;

Boumba et al. 2008;

Dekeirsschieter et al. 2009) $)^{3,6}$

(O'Neal and Poklis 1996; Gill-King 1999;

Dent et al. 2004; Statheropoulos et al. 2005;

Boumba et al. 2008;

Dekeirsschieter et al. 2009) $)^{1,2,3,6}$

(O'Neal and Poklis 1996;

Dekeirsschieter et al. 2009) $)^{1,2,3}$

(Derrick and Large 1993; Boumba et al. 2008)

(Derrick and Large 1993; O`Neal and

Poklis 1996; Boumba et al. 2008;

Dekeirsschieter et al. 2009;

Ercolini et al. 2009; $)^{1,2,3,18}$

(Lorenzo et al. 2003; Statheropoulos et al. 2005;

Vass et al. 2008; Boumba et al. 2008;

Dekeirsschieter et al. 2009;

Hoffman et al. 2009) $)^{1,2,3,5,6,8}$

(Stutz et al. 1991; Haze et al. 2001;

Statheropoulos et al. 2005;

Hoffman et al. 2009)

(Vass et al. 2004; Statheropoulos et al. 2007;

Dekeirsschieter et al. 2009;

Ercolini et al. 2009;

Hoffman et al. 2009)

(Haze et al. 2001; Combet et al. 2006; Hoffman et al. 2009) $)^{8,9}$

(Zhang et al. 1992; Combet et al. 2006;

Ercolini et al. 2009;

Hoffman et al. 2009) ${ }^{8,18,19}$

(Gottschalk 1986;

Dekeirsschieter et al. 2009) $)^{1,2}$

(Gottschalk 1986; Dent et al. 2004;

Boumba et al. 2008)

(Gill-King 1999; Statheropoulos et al. 2005;

Boumba et al. 2008;

Dekeirsschieter et al. 2009;

Hoffman et al. 2009; $)^{1,2,3,6,8}$ 
Table 3 (continued)

\begin{tabular}{|c|c|c|c|}
\hline Compound & $\begin{array}{l}\text { CAS } \\
\text { number }\end{array}$ & Origin & Publication \\
\hline Butanoic acid & $107-92-6$ & $\begin{array}{l}\text { Carbohydrates, lipids } \\
\text { (Boumba et al. 2008), } \\
\text { amino acids } \\
\text { (Demeyer and Vannevel 1979) }\end{array}$ & $\begin{array}{l}\text { (Gill-King 1999; Lorenzo et al. 2003; } \\
\text { Dent et al. 2004; Statheropoulos et al. 2005; } \\
\text { Boumba et al. 2008; Dekeirsschieter et al. 2009; } \\
\text { Hoffman et al. 2009) })^{1,2,3,6,8}\end{array}$ \\
\hline Pentanoic acid & $109-52-4$ & $\begin{array}{l}\text { Amino acids } \\
\text { (Demeyer and Vannevel 1979) }\end{array}$ & $\begin{array}{l}\text { (Lorenzo et al. 2003; Dekeirsschieter et al. 2009; } \\
\text { Hoffman et al. 2009; })^{1,2,3,8}\end{array}$ \\
\hline Hexanoic acid & $142-62-1$ & $\begin{array}{l}\text { Indolic/phenolic compounds } \\
\text { (Young and Rivera 1985) }\end{array}$ & $\begin{array}{l}\text { (Lorenzo et al. 2003; Dekeirsschieter et al. 2009; } \\
\text { Hoffman et al. 2009) }\end{array}$ \\
\hline Tetradecanoic acid & $544-63-8$ & Lipids (Gill-King 1999) & $\begin{array}{l}\text { (Forbes et al. 2002, 2005a, b, c; } \\
\text { Notter et al. 2009) }\end{array}$ \\
\hline Hexadecanoic acid & $57-10-3$ & Lipids (Gill-King 1999) & $\begin{array}{l}\text { (Forbes et al. 2002, 2005a, b, c; } \\
\text { Notter et al. 2009) }\end{array}$ \\
\hline Octadecanoic acid & $57-11-4$ & Lipids (Gill-King 1999) & $\begin{array}{l}\text { (Forbes et al. 2002, 2005a, b, c; } \\
\text { Notter et al. 2009) }\end{array}$ \\
\hline 9-Octadecenoic acid & $112-80-1$ & Lipids (Gill-King 1999) & $\begin{array}{l}\text { (Yan et al. 2001; Forbes et al. 2002, 2005a, b, c; } \\
\text { Notter et al. 2009) }\end{array}$ \\
\hline$(Z, Z)-9,12$-Octadecadienoic acid & $60-33-3$ & Lipids (Gill-King 1999) & (Nushida et al. 2008; Notter et al. 2009) $^{15,16}$ \\
\hline 10-Hydroxyoctadecanoic acid & $638-26-6$ & Lipids (Gill-King 1999) & $\begin{array}{l}\text { (Forbes et al. 2002; } \\
\text { Forbes et al. 2005a, b, c) }{ }^{11,12,13,14}\end{array}$ \\
\hline \multicolumn{4}{|l|}{ Esters } \\
\hline Acetic acid propyl ester & $109-60-4$ & & $\begin{array}{l}\text { (Statheropoulos et al. 2005; } \\
\text { Dekeirsschieter et al. 2009) }\end{array}$ \\
\hline Butanoic acid ethyl ester & $105-54-4$ & & (Statheropoulos et al. 2005; Hoffman et al. 2009) $^{6,8}$ \\
\hline Butanoic acid butyl ester & $109-21-7$ & & $\begin{array}{l}\text { (Lorenzo et al. 2003; Dekeirsschieter et al. 2009; } \\
\text { Hoffman et al. 2009; ) } \text { ) }^{1,2,3,8}\end{array}$ \\
\hline \multicolumn{4}{|l|}{ Aldehydes } \\
\hline Butanal & $123-72-8$ & Alkanes (Arp 1999) & $\begin{array}{l}\text { (Stutz et al. 1991; Vass et al. 2008; } \\
\text { Dekeirsschieter et al. 2009) }\end{array}$ \\
\hline Pentanal & $110-62-3$ & Lipids (Boumba et al. 2008) & $\begin{array}{l}\text { (Statheropoulos et al. 2005; Vass et al. 2008; } \\
\text { Dekeirsschieter et al. 2009) }\end{array}$ \\
\hline Hexanal & $66-25-1$ & Lipids (Boumba et al. 2008) & $\begin{array}{l}\text { (Haze et al. 2001; Lorenzo et al. 2003; } \\
\text { Statheropoulos et al. 2005; Hoffman et al. 2009; } \\
\text { Ercolini et al. 2009) }\end{array}$ \\
\hline Heptanal & $111-71-7$ & Lipids (Boumba et al. 2008) & $\begin{array}{l}\text { (Stutz et al. 1991; Haze et al. 2001; } \\
\text { Lorenzo et al. 2003; Vass et al. 2008; } \\
\text { Dekeirsschieter et al. 2009; } \\
\text { Hoffman et al. 2009) })^{1,2,5,8,9,17}\end{array}$ \\
\hline Nonanal & $124-19-6$ & Lipids (Boumba et al. 2008) & $\begin{array}{l}\text { (Haze et al. 2001; Vass et al. 2004; } \\
\text { Vass et al. 2008; Ercolini et al. 2009; } \\
\text { Hoffman et al. 2009) }\end{array}$ \\
\hline Decanal & $112-31-2$ & & (Vass et al. 2004; Vass et al. 2008) ${ }^{4,5}$ \\
\hline \multicolumn{4}{|l|}{ Ketones } \\
\hline Acetone & $67-64-1$ & $\begin{array}{l}\text { Carbohydrates } \\
\text { (Boumba et al. 2008) }\end{array}$ & $\begin{array}{l}\text { (Stutz et al. 1991; O'Neal and Poklis 1996; } \\
\text { Gill-King 1999; Vass et al. 2004; } \\
\text { Dent et al. 2004; Statheropoulos et al. 2005; } \\
\text { Statheropoulos et al. 2007; Boumba et al. 2008; } \\
\text { Dekeirsschieter et al. 2009) }\end{array}$ \\
\hline Butan-2-one & $78-93-3$ & Alkanes (Patel et al. 1979) & $\begin{array}{l}\text { (Stutz et al. 1991; Statheropoulos et al. 2005; } \\
\text { Statheropoulos et al. 2007; } \\
\text { Dekeirsschieter et al. 2009) }\end{array}$ \\
\hline Pentan-2-one & $107-87-9$ & Alkanes (Patel et al. 1979) & $\begin{array}{l}\text { (Statheropoulos et al. 2005; } \\
\text { Dekeirsschieter et al. 2009) }\end{array}$ \\
\hline Cyclohexanone & $108-94-1$ & $\begin{array}{l}\text { Indolic/phenolic compounds } \\
\text { (Young and Rivera 1985) }\end{array}$ & $\begin{array}{l}\text { (Statheropoulos et al. 2005; } \\
\text { Hoffman et al. 2009) }\end{array}$ \\
\hline
\end{tabular}


Table 3 (continued)

\begin{tabular}{llll}
\hline Compound & $\begin{array}{l}\text { CAS } \\
\text { number }\end{array}$ & Origin & Publication \\
\hline
\end{tabular}

Heptan-2-one

$110-43-0$

Nonan-2-one

$821-55-6$

Lipids

(Boumba et al. 2008)

Homoaromatic compounds

Benzene

$71-43-2$

Methylbenzene

1,2-Dimethylbenzene

95-47-6

1,3-Dimethylbenzene

108-38-3

1,4 Dimethylbenzene

$106-42-3$

1,2,3-Trimethylbenzene

526-73-8

Ethylbenzene

Ethenylbenzene

1-Methyl-2-ethylbenzene

2-Phenyl-propan-2-ol

Phenol

4-Methylphenol

2-Phenylethanol

Benzaldehyde

Acetophenone

1-Methoxy-propylbenzene

Naphthalene

$100-41-4$

$100-42-5$

611-14-3

617-94-7

108-95-2

106-44-5 Tyrosine

(Bone et al. 1976)

60-12-8 Phenylalanine

(Luengo et al. 2001)

100-52-7 Phenylalanine

(Moller et al. 1998)

98-86-2 Phenylalanine

(Rabus and Heider 1998)

59588-12-4

91-20-3

Nitrogen compounds

Trimethylamine

$75-50-3$

Benzonitrile

$100-47-0$

Indole

L-Phenylalanine

(Moller et al. 1998)

Tryptophan
(Statheropoulos et al. 2005;

Dekeirsschieter et al. 2009;

Hoffman et al. 2009) ${ }^{1,2,6,8}$

(Statheropoulos et al. 2007; Vass et al. 2008;

Dekeirsschieter et al. 2009;

Ercolini et al. 2009) ${ }^{1,5,7,18}$

(Statheropoulos et al. 2005; Vass et al. 2008)

(Stutz et al. 1991; Vass et al. 2004;

Statheropoulos et al. 2005;

Statheropoulos et al. 2007;

Vass et al. 2008; Hoffman et al. 2009) $)^{4,5,6,7,8,17}$

(Statheropoulos et al. 2007; Vass et al. 2008) (,7 $^{5}$

(Statheropoulos et al. 2005; Statheropoulos et al. 2007) $)^{6,7}$

(Vass et al. 2004; Statheropoulos et al. 2005; Statheropoulos et al. 2007; Vass et al. 2008; Hoffman et al. 2009) $)^{4,5,6,7,8}$

(Statheropoulos et al. 2005; Statheropoulos et al. 2007) $)^{6,7}$

(Vass et al. 2004; Statheropoulos et al. 2005; Vass et al. 2008) $)^{4,5,6}$

(Vass et al. 2004; Statheropoulos et al. 2007; Vass et al. 2008) $4,5,6$

(Vass et al. 2004; Statheropoulos et al. 2005; Vass et al. 2008) ${ }^{4,5,6}$

(Vass et al. 2004; Vass et al. 2008) (,5 $^{4}$

(Cummings et al. 1979;

Statheropoulos et al. 2007;

Vass et al. 2008;

Dekeirsschieter et al. 2009) ${ }^{1,2,3,5,7,8}$

(Geypens et al. 1997;

Statheropoulos et al. 2007;

Dekeirsschieter et al. 2009) $)^{1,2,3,7}$

(O'Neal and Poklis 1996;

Dekeirsschieter et al. 2009) ${ }^{1}$

(Stutz et al. 1991; Lorenzo et al. 2003;

Vass et al. 2004; Dekeirsschieter et al. 2009; Hoffman et al. 2009) $)^{1,2,4,8,17}$

(Statheropoulos et al. 2007; Dekeirsschieter et al. 2009) $)^{1,2,7}$

(Vass et al. 2004; Vass et al. 2008) (1,5 $^{4}$

(Vass et al. 2004; Statheropoulos et al. 2007; Vass et al. 2008) $)^{4,5,7}$

(Dainty et al. 1989; Stutz et al. 1991; Dekeirsschieter et al. 2009) (1,2,3,17 $^{1}$

(Vass et al. 2004; Dekeirsschieter et al. 2009) $)^{1,2,4}$

(Lopez-Caballero et al. 2001)

(Smith and Macfarlane 1996)
(O'Neal and Poklis 1996; Gill-King 1999; Vass et al. 2002; Lorenzo et al. 2003; Dent et al. 2004; Statheropoulos et al. 2005; Hoffman et al. 2009;

Dekeirsschieter et al. 2009) $)^{3,6,8}$ 
Table 3 (continued)

\begin{tabular}{|c|c|c|c|}
\hline Compound & $\begin{array}{l}\text { CAS } \\
\text { number }\end{array}$ & Origin & Publication \\
\hline \multicolumn{4}{|l|}{ Sulfur compounds } \\
\hline Sulfur dioxide & $7446-09-5$ & & $\begin{array}{l}\text { (Vass et al. 2002; Vass et al. 2004; } \\
\text { Statheropoulos et al. 2005; Vass et al. 2008; } \\
\text { Dekeirsschieter et al. 2009) }\end{array}$ \\
\hline Carbon disulfide & $75-15-0$ & & $\begin{array}{l}\text { (Vass et al. 2004; Statheropoulos et al. 2005; } \\
\text { Vass et al. 2008) }\end{array}$ \\
\hline Methanethiol & $74-93-1$ & $\begin{array}{l}\text { Methionine } \\
\text { (Frederick et al. 1957; } \\
\text { Kadota and Ishida 1972) }\end{array}$ & $\begin{array}{l}\text { (Lindinger et al. 1998; Dekeirsschieter et al. 2009; } \\
\text { Kalinova et al. 2009) }\end{array}$ \\
\hline Dimethyl sulfide & $75-18-3$ & $\begin{array}{l}\text { Methionine } \\
\text { (Dainty et al. 1989) }\end{array}$ & $\begin{array}{l}\text { (Stutz et al. 1991; Lindinger et al. 1998; } \\
\text { Vass et al. 2004; Statheropoulos et al. 2005; } \\
\text { Statheropoulos et al. 2007; Vass et al. 2008; } \\
\text { Kalinova et al. 2009) }\end{array}$ \\
\hline Dimethyl disulfide & $624-92-0$ & $\begin{array}{l}\text { Methanethiol } \\
\text { (Frederick et al. 1957; } \\
\text { Lestremau et al. 2004) }\end{array}$ & $\begin{array}{l}\text { (Stutz et al. 1991; Stensmyr et al. 2002; } \\
\text { Lorenzo et al. 2003; Dent et al. 2004; } \\
\text { Vass et al. 2004; Statheropoulos et al. 2005; } \\
\text { Statheropoulos et al. 2007; Vass et al. 2008; } \\
\text { Dekeirsschieter et al. 2009; Hoffman et al. 2009; } \\
\text { Kalinova et al. 2009) }\end{array}$ \\
\hline Dimethyl trisulfide & $3658-80-8$ & $\begin{array}{l}\text { Methionine } \\
\text { (Wolle et al. 2006) }\end{array}$ & $\begin{array}{l}\text { (Stutz et al. 1991; Stensmyr et al. 2002; } \\
\text { Dent et al. 2004; Vass et al. 2004; } \\
\text { Statheropoulos et al. 2005; } \\
\text { Statheropoulos et al. 2007; Vass et al. 2008; } \\
\text { Dekeirsschieter et al. 2009; } \\
\text { Kalinova et al. 2009) } \text { (1,2,3,4,5,6,7,17,20 }^{\text {Kalno }}\end{array}$ \\
\hline
\end{tabular}

marker volatiles, which are correlated to the time since death, it is possible to use insects as an information filter. Many insects have adapted their olfaction over millions of years to specific cadaveric volatiles (Huotari and Mela 1996; Kaib 1974; Kalinova et al. 2009; Stensmyr et al. 2002). Insects are feasible organisms for olfactory research because electrophysiological methods have been established for many species (Kalinova et al. 2009; Schutz et al. 1999; Stensmyr et al. 2002; Thakeow et al. 2008; Weissbecker et al. 2004), and the molecular basis of insect olfaction has been investigated for decades (Vogt and Riddiford 1981; Wicher et al. 2008). The order Diptera, in which most necrophilic insect species are classified, is relatively easy to breed at a high reproduction rate. Using chemo-ecological methods that combine trace analysis and electrophysiology (Weissbecker et al. 2004), these insects can be used to identify core compounds from the volatile pattern of a dead vertebrate. The existence of a common core of decompositional odors has already been suggested (Dekeirsschieter et al. 2009). Carrion-visiting Diptera can be divided into generalists, such as Calliphora vicina or Lucilia caesar, and specialists that occur in certain stages of decay, such as Hydrotaea aenescens or Hydrotaea meteorica (Matuszewski et al. 2010b). Both types of insects might identify core compounds of vertebrate decay, which occur at any time or in certain stages of decay. In general, insect antennae serve as information filters that help in identifying volatiles for different applications. For instance, a post-mortem interval-correlated qualitative and quantitative dynamic volatile pattern could give an estimate of the time since death (Statheropoulos et al. 2007; Vass et al. 2004) or selected volatiles may improve cadaver dog training (Hoffman et al. 2009). Dimethyl sulfide, dimethyl disulfide, and dimethyl trisulfide are already known as electrophysiologically active for the blowflies $C$. vicina and L. caesar (Stensmyr et al. 2002) and the burying beetles Nicrophorus vespillo and Nicrophorus vespilloides (Kalinova et al. 2009). Such volatiles should be reliable for routine application and could be detected by low-cost and compact trace analysis devices such as semi-conductor gas sensor systems (Kohl 2003; Paczkowski et al. 2011). The tracing of victims of natural disasters, such as those buried in earthquakes, as well as the tracking of victims of homicides whose bodies have been buried (Killam 2004; Statheropoulos et al. 2007; Vass et al. 2008) may be improved by such methods (Statheropoulos et al. 2006). The industrial application of a detector for early vertebrate post-mortem VOCs could help in determining the degree of spoilage or estimation of the storage time of fish and meat (Lindinger et al. 1998; Nicolay 2006; Winquist et al. 1993). 
Table 4 Contains important experimental parameters used in the studies listed in Table 3

\begin{tabular}{|c|c|c|c|c|}
\hline Number & Publication & Tissue & Location & Sampling technique \\
\hline 1 & Dekeirsschieter et al. 2009 & Domestic pig & Belgium, forest & Radiello, passive, 1 week, GC/MS \\
\hline 2 & Dekeirsschieter et al. 2009 & Domestic pig & Belgium, rural & Radiello, passive, 1 week, GC/MS \\
\hline 3 & Dekeirsschieter et al. 2009 & Domestic pig & Belgium, urban & Radiello, passive, 1 week, GC/MS \\
\hline 4 & Vass et al. 2004 & Human & $\begin{array}{l}\text { USA, Tennessee, } \\
\text { open woodland }\end{array}$ & $\begin{array}{l}\text { Triple sorbent traps (Carbotrap, } \\
\text { Carbotrap C, Carbosieve S-III), GC/MS }\end{array}$ \\
\hline 5 & Vass et al. 2008 & $\begin{array}{l}\text { Human, bones } \\
\text { of human, deer, dog }\end{array}$ & $\begin{array}{l}\text { USA, Tennessee, } \\
\text { open woodland }\end{array}$ & $\begin{array}{l}\text { Triple sorbent traps (Carbotrap, } \\
\text { Carbotrap C, Carbosieve S-III), GC/MS }\end{array}$ \\
\hline 6 & Statheropoulos et al. 2005 & Human & Greece, island of Samos & $\begin{array}{l}\text { Three-layer sampling sorbent glass tube } \\
\text { (Carbograph 1, Carbograph 2, } \\
\text { Carbosieve S-III), 51, GC/MS }\end{array}$ \\
\hline 7 & Statheropoulos et al. 2007 & Human & Greece, eastern Attica & $\begin{array}{l}\text { Three-layer sampling sorbend glass tube } \\
\text { (Carbopack B, Carbopack C, } \\
\text { Carbosieve S-III), 5l, GC/MS }\end{array}$ \\
\hline 8 & Hoffman et al. 2009 & Different human tissues & - & $\begin{array}{l}\text { SPME (PDMS/DVB), for } 20 \text { and } \\
40 \text { min in glas vial, GC/MS }\end{array}$ \\
\hline 9 & Haze et al. 2001 & Living human skin & Japan & $\begin{array}{l}\text { TENAX-TA column } \\
\text { (GL Science), 101, GC/MS }\end{array}$ \\
\hline 10 & Yan et al. 2001 & Adipocere & - & - \\
\hline 11 & Forbes et al. $2005 \mathrm{a}$ & Domestic pig adipocere & Australia, laboratory & $\begin{array}{l}1 \mu \mathrm{l} \text { of chloroform extract, } \\
\text { HMDS esterification, GC/MS }\end{array}$ \\
\hline 12 & Forbes et al. $2005 b$ & Domestic pig adipocere & Australia, laboratory & $\begin{array}{l}1 \mu \mathrm{l} \text { of chloroform extract, } \\
\text { HMDS esterification, GC/MS }\end{array}$ \\
\hline 13 & Forbes et al. $2005 \mathrm{c}$ & Domestic pig adipocere & Australia, laboratory & $\begin{array}{l}1 \mu \mathrm{l} \text { of chloroform extract, } \\
\text { HMDS esterification, GC/MS }\end{array}$ \\
\hline 14 & Forbes et al. 2002 & Soil sample beneath coffin & Australia & $\begin{array}{l}1 \mu \mathrm{l} \text { of chloroform extract, } \\
\text { HMDS esterification, GC/MS }\end{array}$ \\
\hline 15 & Notter et al. 2009 & Domestic pig adipocere & Australia, laboratory & $1 \mu \mathrm{l}$ of derivatised sample, GC/MS \\
\hline 16 & Nushida et al. 2008 & Human adipocere & Japan, laboratory & Processed and derivatised sample, GC/MS \\
\hline 17 & Stutz et al. 1991 & Ground beef & Laboratory & Porapak trap, GC/MS \\
\hline 18 & Ercolini et al. 2009 & Beef muscle, latissimus dorsi & Laboratory & $\begin{array}{l}5 \mathrm{~g} \text { homogenized in } 100 \mathrm{ml} \text { water and } \\
30 \mathrm{~g} \mathrm{NaCl} \text {, SPME (CAR/DVB/PDMS) } \\
\text { for } 1 \mathrm{~h}, \mathrm{GC} / \mathrm{MS}\end{array}$ \\
\hline 19 & Zhang et al. 1992 & Ayu skin, arachidonic acid & Japan & $\begin{array}{l}30 \mathrm{ml}(1 \mathrm{mg} \text { protein } / \mathrm{ml})+50 \mu \mathrm{M} \\
\text { arachidonic acid; Tenax TA, } 70 \mathrm{ml} / \mathrm{min} \text {, } \\
90 \mathrm{~min}, \mathrm{GC} / \mathrm{MS}\end{array}$ \\
\hline 20 & Kalinova et al. 2009 & Mouse (Mus musculus) & Laboratory & $\begin{array}{l}\text { SPME }(\mathrm{CAR} / \mathrm{PDMS}) \text { for } 15 \mathrm{~min} \text { in } \\
\text { glass container, } \mathrm{GC} \times \mathrm{GC}-\mathrm{TOFMS}\end{array}$ \\
\hline
\end{tabular}

Although the formation of biogenic amines is known to be correlated with microbial growth on vertebrate tissue, most of these compounds have a low volatility and, therefore, are not useful for a volatile-based quality estimation. Histamine, putrescine, cadaverine, tyramine, tryptamine, $\beta$-phenylethylamine, spermine, and spermidine are reported to be the most important biogenic amines (Onal 2007). Especially putrescine and cadaverine were regarded as important volatile products of vertebrate decay; however, all of the listed amines have a low volatility and, therefore, are not frequently identified in analytical literature on cadaveric volatiles (Table 3 ). Together with lipid acid formation during the formation of adipocere, biogenic amines could be important in estimating the pmi by means of liquid chromatography or SPME liquid extraction (Onal 2007). However, gas sensor systems would most likely not be able to detect them. On the other hand, ammonia might play an important role in aging vertebrate tissue. Olafsdottir and Kristbersson (2006) discuss the performance of electronic noses for the quality estimation of fresh fish. As gas sensors are restricted in selecting single compounds from an odor, the authors refer to compound groups such as sulfur compounds, volatile amines like ammonia, esters, aldehydes, or alcohols. The quantitative emission of compounds from these groups did correlate with the signals of three gas sensors. Hence, fish storage time was 
detectable for the sensor array in this experiment. Winquist et al. used an array of 15 gas sensors detecting hydrogen, hydrogen sulfide, amines, alcohols, saturated hydrocarbons, and humidity in order to estimate the spoilage of ground beef (Winquist et al. 1993). In this study, a three-layerpattern recognition routine was used in order to train the electronic nose on the recognition of the type of meat and the storage time. It was possible to determine the type of meat and the storage time of ground pork and beef; however, the authors state that in this experiment variation was minimal in comparison to the potential variation in practice. The quantitative emissions of the compound classes may vary to a high extent and important volatile cues might be under the detection threshold for gas sensors. For instance, Lindinger et al. detected methanethiol in parts-per-billion concentrations in the headspace of beef meat stored at $22{ }^{\circ} \mathrm{C}$ (Lindinger et al. 1998). As already described in this review, methanethiol is a good candidate for meat spoilage detection; however, it has to be evaluated if gas sensors are able to detect the compound at such a concentration level. Furthermore, meat stored at chill temperatures will develop a psychrotrophic micro-fauna, consisting of lactic acid bacteria and Pseudomonas spp. or Enterobacteriaceae. The volatile profile of these bacteria will differ from the volatile profile of micro-organisms growing at ambient temperatures. Ercolini et al. investigated the odor profile of psychrotrophic micro-organisms and did not find methanethiol (Ercolini et al. 2009), which indicates that this compound might form only at elevated temperatures. Rajamaki et al. found an increasing quantity of dimethyl disulfide in the headspace of broiler chicken at an elevated temperature, which might have formed from methanethiol (Rajamaki et al. 2006). Hence, methanethiol or the associated methylated sulfides could be markers for the inappropriate storage of meat at elevated temperatures. In the study of Rajamäki et al., a commercial electronic nose with a principal component analysis detected hydrogen sulfide concentrations, which allowed one to determine spoilage on meat packed under a modified atmosphere (Rajamaki et al. 2006). However, gas sensor technology has to be improved to enable the detection of low concentrations of single compounds for a reliable spoilage estimation. This improvement can be achieved by immobilizing proteins on sensor surfaces to utilize the strong odor detection abilities in nature (Hou et al. 2005; Khanna et al. 2006) or by varying the operating temperature for enhanced gas sensor selectivity (Sauerwald et al. 2007).

\section{Conclusion}

This review highlights the VOC emissions of dead vertebrates based on data from experimental trace analysis and their formation. There is a correlation between the information on biochemical processes and phenomenological results. For some volatiles, the pathways of their formation are entirely unknown or not known in detail. In particular, the detailed processes of fat degradation in prokaryotes are unknown. Based on existing information in the literature, it may be possible to hypothesize a core pattern of volatile emission during decay. After death, the volatiles produced by ROS might be the first to give rise to changes, and this event would be accompanied by the increasing growth of microbes that metabolize the fat on the skin and lead to decomposition by the tissues' own enzymes. Once the immune system fails, the microbes that are already present inside the respiratory tract or in the gastrointestinal tract would contribute to the volatile pattern of decay. The metabolic products of particular intestinal microbes cause bloating under anaerobic conditions. This influences the microbial species composition and therefore gives rise to other volatile metabolic products. Breakage of the skin leads to the entry of oxygen, which again favors different microbes, yielding different volatiles. In an oxidative environment, secondary volatile products might form. During advanced dry decay, most of the carbohydrates and proteins are degraded. The volatiles produced by ROS and the microbial decomposition of bone components might dominate at this stage. Throughout this process, microbes might interact and thereby influence the pattern of the volatiles released. At present, information on vertebrate decay is incomplete. Therefore, the idea of a core pattern of volatiles of vertebrate decay remains a hypothesis. Further research on the application of post-mortem volatiles should integrate the knowledge of microbiologists and forensic scientists in order to perform experiments on the biochemical origin of these volatiles. The evolutional preadaption of insect olfaction to the perception of decompositional volatiles may help in developing volatile-based methods for forensic science, such as postmortem time estimation or cadaver dog training.

Acknowledgement The Cusanuswerk, Bischöfliche Studienstiftung, kindly supports the work of Sebastian Paczkowski.

Open Access This article is distributed under the terms of the Creative Commons Attribution Noncommercial License which permits any noncommercial use, distribution, and reproduction in any medium, provided the original author(s) and source are credited.

\section{References}

Alexieva Z, Gerginova M, Manasiev J, Zlateva P, Shivarova N, Krastanov A (2008) Phenol and cresol mixture degradation by the yeast Trichosporon cutaneum. J Ind Microbio Biot 35:1297-1301

Amendt J, Krettek R, Zehner R (2004) Forensic entomology. Naturwissenschaften 91:51-65

Ansorena D, Montel MC, Rokka M, Talon R, Eerola S, Rizzo A, Raemaekers M, Demeyer D (2002) Analysis of biogenic amines 
in northern and southern European sausages and role of flora in amine production. Meat Sci 61:141-147

Arp DJ (1999) Butane metabolism by butane-grown Pseudomonas butanovora. Microbiol-UK 145:1173-1180

Bone E, Tamm A, Hill M (1976) Production of urinary phenols by gut bacteria and their possible role in causation of large bowel cancer. Am J Clin Nutr 29:1448-1454

Borjesson TS, Stollman UM, Schnurer JL (1993) Off-odorous compounds produced by molds on oatmeal agar-identification and relation to other growth-characteristics. J Agr Food Chem 41:2104-2111

Boschker HTS, Middelburg JJ (2002) Stable isotopes and biomarkers in microbial ecology. FEMS Microbiol Ecol 40:85-95

Boumba VA, Ziavrou KS, Vougiouklakis T (2008) Biochemical pathways generating post-mortem volatile compounds co-detected during forensic ethanol analyses. Forensic Sci Int 174:133-151

Branscheid W, Honikel KO, vLengerken G, Troeger K (2007) Qualität von Fleisch- und Fleischwaren. Deutscher Fachverlag, Frankfurt

Bryant MP, Wolin EA, Wolin MJ, Wolfe RS (1967) Methanobacillus omelianskii, a symbiotic association of 2 species of bacteria. Arch Mikrobiol 59:20-31

Cadenas E (1989) Biochemistry of oxygen-toxicity. Annu Rev Biochem 58:79-110

Carter DO, Yellowlees D, Tibbett M (2007) Cadaver decomposition in terrestrial ecosystems. Naturwissenschaften 94:12-24

Chang J, Kollman SE (1989) The effect of temperature on the formation of ethanol by Candida-albicans in blood. J Forensic Sci 34:105-109

Chen ECH (1978) Relative contribution of Ehrlich and biosynthetic pathways to the formation of fusel alcohols. J Am Soc Brew Chem 36:39-43

Choe E, Min DB (2005) Chemistry and reactions of reactive oxygen species in foods. J Food Sci 70:142-159

Combet E, Henderson J, Eastwood CD, Burton KS (2006) Eightcarbon volatiles in mushrooms and fungi: properties analysis and biosynthesis. Mycoscience 47:317-326

Corry JEL (1978) Possible sources of ethanol ante-mortem and postmortem - its relationship to biochemistry and microbiology of decomposition. J Appl Bacteriol 44:1-56

Cummings JH, Hill MJ, Bone ES, Branch WJ, Jenkins DJA (1979) Effect of meat protein and dietary fiber on colonic function and metabolism. 2. Bacterial metabolites in feces and urine. Am J Clin Nutr 32:2094-2101

Dainty RH, Edwards RA, Hibbard CM (1985) Time course of volatile compound formation during refrigerated storage of naturally contaminated beef in air. J Appl Bacteriol 59:303-309

Dainty RH, Edwards RA, Hibbard CM, Marnewick JJ (1989) Volatile compounds associated with microbial-growth on normal and high ph beef stored at chill temperatures. J Appl Bacteriol 66:281-289

Davis GL, Leffert RL, Rantanen NW (1972) Putrefactive ethanol sources in postmortem tissues of conventional and germ-free mice. Arch Pathol 94:71-74

Dekeirsschieter J, Verheggen FJ, Gohy M, Hubrecht F, Bourguignon L, Lognay G, Haubruge E (2009) Cadaveric volatile organic compounds released by decaying pig carcasses (Sus domesticus L.) in different biotopes. Forensic Sci Int 189:46-53

Demeyer D, Vannevel C (1979) Protein fermentation and growth by rumen microbes. Ann Rech Vet 10:277-279

Dent BB, Forbes SL, Stuart BH (2004) Review of human decomposition processes in soil. Environ Geol 45:576-585

Derrick S, Large PJ (1993) Activities of the enzymes of the Ehrlich pathway and formation of branched-chain alcohols in Saccharomyces-cerevisiae and Candida-utilis grown in continuous-culture on valine or ammonium as sole nitrogen-source. J Gen Microbiol 139:2783-2792

Dotterl S, Burkhardt D, Weissbecker B, Jurgens A, Schutz S, Mosandl A (2006) Linalool and lilac aldehyde/alcohol in flower scents- electrophysiological detection of lilac aldehyde stereoisomers by a moth. J Chromatogr A 1113:231-238

Dransfield E (1992) Modeling postmortem tenderization. 3. Role of calpain-I in conditioning. Meat Sci 31:85-94

Durlu-Özkaya F, Ayhan K, Vural N (2001) Biogenic amines produced by Enterobacteriaceae isolated from meat products. Meat Sci 58:163-166

Dutson TR (1983) Relationship of ph and temperature to disruption of specific muscle proteins and activity of lysosomal proteases. J Food Biochem 7:223-245

Ercolini D, Russo F, Nasi A, Ferranti P, Villani F (2009) Mesophilic and psychrotrophic bacteria from meat and their spoilage potential in vitro and in beef. Appl Environ Microb 75:1990-2001

Estevez M, Morcuende D, Ventanas S, Cava R (2003) Analysis of volatiles in meat from Iberian pigs and lean pigs after refrigeration and cooking by using SPME-GC-MS. J Agr Food Chem 51:3429-3435

Evans WC (1963) Microbiological degradation of aromatic compounds. J Gen Microbiol 32:177-184

Evershed RP, Turnerwalker G, Hedges REM, Tuross N, Leyden A (1995) Preliminary-results for the analysis of lipids in ancient bone. J Archeol Sci 22:277-290

Fernando WGD, Ramarathnam R, Krishnamoorthy AS, Savchuk SC (2005) Identification and use of potential bacterial organic antifungal volatiles in biocontrol. Soil Biol Biochem 37:955-964

Feussner I, Kühn H, Wasternack C (1997) Do specific linoleate 13lipoxygenases initiate B-oxidation? FEBS Lett 406:1-5

Forbes SL, Stuart BH, Dent BB (2002) The identification of adipocere in grave soils. Forensic Sci Int 127:225-230

Forbes SL, Dent BB, Stuart BH (2005a) The effect of soil type on adipocere formation. Forensic Sci Int 154:35-43

Forbes SL, Stuart BH, Dent BB (2005b) The effect of the burial environment on adipocere formation. Forensic Sci Int 154:24-34

Forbes SL, Stuart BH, Dent BB (2005c) The effect of the method of burial on adipocere formation. Forensic Sci Int 154:44-52

Frankel EN (1983) Volatile lipid oxidation-products. Prog Lipid Res 22:1-33

Frederick LR, Starkey RL, Segal W (1957) Decomposability of some organic sulphur compounds in soil. P Soil Sci Soc Am 21:287-292

Freney JR (1967) Sulphur-containing organics. In: Mac Laren AD, Peterson GH (eds) Soil biochemistry. Marcel Dekker, New York, pp 229-259

Gandemer G (2002) Lipids in muscles and adipose tissues changes during processing and sensory properties of meat products. Meat Sci 62:309-321

Geypens B, Claus D, Evenepoel P, Hiele M, Maes B, Peeters M, Rutgeerts P, Ghoos Y (1997) Influence of dietary protein supplements on the formation of bacterial metabolites in the colon. Gut 41:70-76

Gilbert RG, Menzies JD, Griebel GE (1969) Influence of volatiles from alfalfa upon growth and survival of soil microorganisms. Phytopathology 59:992-995

Gill CO, Penney N, Nottingham PM (1976) Effect of delayed evisceration on microbial quality of meat. Appl Environ Microbiol 31:465-468

Gill-King H (1999) Chemical and ultrastructural aspects of decomposition. In: Haglund WD, Sorg MH (eds) Forensic taphonomy. The postmortem fate of human remains. CRC, Boca Raton, pp 93-108

Goll DE, Otsuka Y, Nagainis PA, Shannon JD, Sathe SK, Muguruma M (1983) Role of muscle proteinases in maintenance of muscle integrity and mass. J Food Biochem 7:137-177

Gottschalk G (1986) Bacterial metabolism. Springer, New York

Gray TRG, Williams ST (1971) Soil microorganisms. Oliver and Boyd, Edinburgh

Gu YQ, Mo MH, Zhou JP, Zou CS, Zhang KQ (2007) Evaluation and identification of potential organic nematicidal volatiles from soil bacteria. Soil Biol Biochem 39:2567-2575 
Gulzow HJ (1982) On the anaerobic transformation of palatinit by microorganisms of the human oral cavity. Deut Zahnarztl Z 37:669-672

Gurr MI (1988) Lipid-metabolism in man. P Nutr Soc 47:277-285

Haagsma J (1991) Pathogenic anaerobic bacteria and the environment. Rev Sci Tech 10:749-764

Haglund WD (1997) Dogs and coyotes: postmortem involvement with human remains. In: Haglund WD, Sorg MH (eds) Forensic taphonomy: the postmortem fate of human remains. CRC, Boca Raton, pp 367-382

Haze S, Gozu Y, Nakamura S, Kohno Y, Sawano K, Ohta H, Yamazaki K (2001) 2-Nonenal newly found in human body odor tends to increase with aging. J Invest Dermatol 116:520-524

Heath RJ, Jackowski S, Rock CO (2002) Fatty acid and phospholipid metabolism in prokaryotes. In: Vance DE, Vance JE (eds) Biochemistry of lipids, lipoproteins and membranes. Elsevier, Amsterdam, pp 55-92

Herrera MC, Duque E, Rodriguez-Herva JJ, Fernandez-Escamilla AM, Ramos JL (2010) Identification and characterization of the PhhR regulon in Pseudomonas putida. Environ Microbiol 12:1427-1438

Higgins IJ, Burns RG (1975) The chemistry and microbiology of pollution. Academic, London

Hoffman EM, Curran AM, Dulgerian N, Stockham RA, Eckenrode BA (2009) Characterization of the volatile organic compounds present in the headspace of decomposing human remains. Forensic Sci Int 186:6-13

Hopkins DW, Wiltshire PEJ, Turner BD (2000) Microbial characteristics of soils from graves: arm investigation at the interface of soil microbiology and forensic science. Appl Soil Ecol 14:283-288

Hou YX, Jaffrezic-Renault N, Martelet C, Tlili C, Zhang A, Pernollet JC, Briand L, Gomila G, Errachid A, Samitier J, Salvagnac L, Torbiero B, Temple-Boyer P (2005) Study of Langmuir and Langmuir-Blodgett films of odorant-binding protein/amphiphile for odorant biosensors. Langmuir 21:4058-4065

Hübschmann H-J (2009) Handbook of GC/MS. Wiley-VCH, Weinheim

Huotari M, Mela M (1996) Blowfly olfactory biosensor's sensitivity and specificity. Sensors Actuat B-Chem 34:240-244

Iannotti EL, Kafkewit D, Wolin MJ, Bryant MP (1973) Glucose fermentation products of Ruminococcus-albus grown in continuous culture with Vibrio succinogenes - changes caused by interspecies transfer of $\mathrm{H}_{2}$. J Bacteriol 114:1231-1240

Insausti K, Goni V, Petri E, Gorraiz C, Beriain MJ (2005) Effect of weight at slaughter on the volatile compounds of cooked beef from Spanish cattle breeds. Meat Sci 70:83-90

Ito T, Ando T, Mayahara H, Miyajima H, Ogawa K (1991a) Postmortem changes in the rat-kidney. 1. Histopathological electron-microscopic and enzyme histochemical-studies of postmortem changes at roomtemperature. Acta Histochem Cytoc 24:135-151

Ito T, Ando T, Mayahara H, Miyajima H, Ogawa K (1991b) Postmortem changes in the rat-kidney. 2. Histopathological electron-microscopic and enzyme histochemical-studies of postmortem changes at 0-degrees-C. Acta Histochem Cytoc 24:153166

Jay JM (2000) Food preservation with chemicals. Aspen, Gaithersburg

Jenny J (1983) Bacteriology, mycology and parasitology of the vaginafrequency and clinical-significance of the different microorganisms. Schweiz Rundsch Med 72:1515-1520

Kadota HG, Ishida Y (1972) Production of volatile sulphur compounds by micro-organisms. Ann Revf Microbiol 26:127-138

Kai M, Haustein M, Molina F, Petri A, Scholz B, Piechulla B (2009) Bacterial volatiles and their action potential. Appl Microbiol Biotechnol 81:1001-1012

Kaib M (1974) Receptors for meat-odor and flower-odor on antenna of blowfly Calliphora vicina. J Comp Phys 95:105-121

Kalinova B, Podskalska H, Ruzicka J, Hoskovec M (2009) Irresistible bouquet of death-how are burying beetles (Coleoptera: Silphi- dae: Nicrophorus) attracted by carcasses. Naturwissenschaften 96:889-899

Khanna VK, Kumar A, Jain YK, Ahmad S (2006) Design and development of a novel high-transconductance pH-ISFET (ionsensitive field-effect transistor)-based glucose biosensor. Int $\mathrm{J}$ Electron 93:81-96

Killam EW (2004) The detection of human remains. Thomas, Springfield

King JE, Coley-Smith JR (1969) Production of volatile alkyl sulphides by microbial degradation of synthetic alliin and alliin-like compounds in relation to germination of sclerotia of Sclerotium cepivorum Berk. Ann Appl Biol 64:303-314

Kionka C, Kunau WH (1985) Inducible beta-oxidation pathway in Neurospora-crassa. J Bacteriol 161:153-157

Kohl C-D (2003) Electronic noses. In: Waser R (ed) Nanoelectronics and information technology-advanced electronic materials and novel devices. Wiley-VCH, Berlin

Koohmaraie M (1992) The role of $\mathrm{Ca}(2+)$-dependent proteases (calpains) in postmortem proteolysis and meat tenderness. Biochimie 74:239 245

Koohmaraie M (1994) Muscle proteinases and meat aging. Meat Sci 36:93-104

Korpi A, Pasanen AL, Pasanen P (1998) Vblatile compounds originating from mixed microbial cultures on building materials under various humidity conditions. Appl Environ Microbiol 64:2914-2919

Labows JL (1982) Skin microorganisms and body odors. J Soc Cosmet Chem 33:369

Larsen TO, Frisvad JC (1995) Comparison of different methods for collection of volatile chemical markers from fungi. J Microbiol Meth 24:135-144

LeBlanc HN, Logan JG (2010) Exploiting insect olfaction in forensic entomology. In: Amendt J, Campobasso CP, Goff ML, Grassberger $M$ (eds) Current concepts in forensic entomology. Springer, New York, pp 205-222

Lee JH, Waller JC, Melton SL, Saxton AM, Pordesimo LO (2004) Feeding encapsulated ground full-fat soybeans to increase polyunsaturated fat concentrations and effects on flavor volatiles in fresh lamb. J Anim Sci 82:2734-2741

Lestremau F, Andersson FAT, Desauziers V (2004) Investigation of artefact formation during analysis of volatile sulphur compounds using solid phase microextraction (SPME). Chromatographia 59:607-613

Lewis JA, Papavizas GC (1972) Evolution of volatile sulphurcontaining compounds from decomposition of crucifers in soil. Soil Biol Biochem 2:239-246

Lindinger W, Hansel A, Jordan A (1998) Proton-transfer-reaction mass spectrometry (PTR-MS): on-line monitoring of volatile organic compounds at pptv levels. Chem Soc Rev 27:347-354

Lopez-Caballero ME, Sanchez-Fernandez JA, Moral A (2001) Growth and metabolic activity of Shewanella putrefaciens maintained under different $\mathrm{CO}_{2}$ and $\mathrm{O}_{2}$ concentrations. Int $\mathrm{J}$ Food Microbiol 64:277-287

Lorenzo N, Wan TL, Harper RJ, Hsu YL, Chow M, Rose S, Furton KG (2003) Laboratory and field experiments used to identify canis lupus var. familiaris active odor signature chemicals from drugs, explosives, and humans. Anal Bioanal Chem 376:12121224

Luengo JM, Garcia JL, Olivera ER (2001) The phenylacetyl-CoA catabolon: a complex catabolic unit with broad biotechnological applications. Mol Microbiol 39:1434-1442

Macfarlane GT, Allison C (1986) Utilisation of protein by human gut bacteria. FEMS Microbiol Ecol 38:19-24

Marinho AND, Miranda NC, Braz V, Ribeiro-dos-Santos AK, deSouza SMFM (2006) Paleogenetic and taphonomic analysis of human bones from Moa Beirada and Ze Espinho Sambaquis Rio de Janeiro Brazil. Mem do I Oswaldo Cruz 101:15-23

Matuszewski S, Bajerlein D, Konwerski S, Szpila K (2010a) Insect succession and carrion decomposition in selected forests of 
Central Europe. Part 1: pattern and rate of decomposition. Forensic Sci Int 194:85-93

Matuszewski S, Bajerlein D, Konwerski S, Szpila K (2010b) Insect succession and carrion decomposition in selected forests of Central Europe. Part 2: composition and residency patterns of carrion fauna. Forensic Sci Int 195:42-51

Meier-Augenstein W (2002) Stable isotope analysis of fatty acids by gas chromatography-isotope ratio mass spectrometry. Anal Chim Acta 465:63-79

Michaud JP, Moreau G (2011) A statistical approach based on accumulated degree-days to predict decomposition-related processes in forensic studies. J Forensic Sci 56:229-232

Miller WC, Palmer WK, Arnall DA, Oscai LB (1987) Characterization of the triacylglycerol lipase activity in 3 types of rat skeletalmuscle. Can J Physiol Pharm 65:317-322

Molin G, Ternstrom A (1986) Phenotypically based taxonomy of psychrotrophic Pseudomonas isolated from spoiled meat water and soil. Int J Syst Bacteriol 36:257-274

Moller JKS, Hinrichsen LL, Andersen HJ (1998) Formation of amino acid (L-leucine L-phenylalanine) derived volatile flavour compounds by Moraxella phenylpyruvica and Staphylococcus xylosus in cured meat model systems. Int J Food Microbiol 42:101-117

Moore WEC, Holdeman LV (1974) Human fecal flora-normal flora of 20 Japanese-Hawaiians. Appl Microbiol 27:961-979

Moreno-Opo R, Margalida A, Arredondo A, Guil F, Martin M, Higuero R, Soria C, Guzman J (2010) Factors influencing the presence of the cinereous vulture Aegypius monachus at carcasses: food preferences and implications for the management of supplementary feeding sites. Wildlife Biol 16:25-34

Motilva MJ, Toldra F, Nieto P, Flores J (1993) Muscle lipolysis phenomena in the processing of dry-cured ham. Food Chem 48:121-125

Negre AE, Salvayre RS, Dagan A, Gatt S (1985) New fluorometric assay of lysosomal acid lipase and its application to the diagnosis of Wolman and cholesteryl ester storage diseases. Clin Chim Acta $149: 81-88$

Nicolay X (2006) Odors in the food industry. Springer, New York

Notter SJ, Stuart BH, Rowe R, Langlois N (2009) The initial changes of fat deposits during the decomposition of human and pig remains. J Forensic Sci 54:195-201

Nushida H, Adachi J, Takeuchi A, Asano M, Ueno Y (2008) Adipocere formation via hydrogenation of linoleic acid in a victim kept under dry concealment. Forensic Sci Int 175:160-165

Okuda H (1991) Lipases. In: Kuby SA (ed) A study of enzyme action. CRC, Boca Raton, pp 579-593

Olafsdottir G, Kristbergsson K (2006) Electronic-nose technology: application for quality evaluation in the fish industry. In: Nicolay $\mathrm{X}$ (ed) Odors in the food industry. Springer, New York, pp 57-74

Onal A (2007) A review: current analytical methods for the determination of biogenic amines in foods. Food Chem 103:1475-1486

O'Neal CL, Poklis A (1996) Postmortem production of ethanol and factors that influence interpretation - a critical review. Am J Foren Med Path 17:8-20

Paczkowski S, Weißbecker B, Schöning MJ, Schütz S (2011) Biosensors on the basis of insect olfaction. In: Vilcinskas A (ed) Insect biotechnology. Springer, Dordrecht, pp 225-240

Pasanen AL, Lappalainen S, Pasanen P (1996) Volatile organic metabolites associated with some toxic fungi and their mycotoxins. Analyst 121:1949-1953

Patel RN, Hou CT, Laskin AI, Derelanko P, Felix A (1979) Microbialproduction of methyl ketones - purification and properties of a secondary alcohol-dehydrogenase from yeast. Eur J Biochem 101:401-406

Patel RN, Hou CT, Laskin AI, Felix A, Derelanko P (1980) Microbial oxidation of gaseous hydrocarbons - production of secondary alcohols from corresponding normal-alkanes by methaneutilizing bacteria. Appl Environ Microbiol 39:720-726

Polson CJ, Gee DJ, Knight B (1985) The essentials of forensic medicine. Pergamon, Oxford

Rabus R, Heider J (1998) Initial reactions of anaerobic metabolism of alkylbenzenes in denitrifying and sulphate reducing bacteria. Arch Microbiol 170:377-384

Rajamaki T, Alakomi HL, Ritvanen T, Skytta ES, Smolander M, Ahvenainen R (2006) Application of an electronic nose for quality assessment of modified atmosphere packaged poultry meat. Food Control 17:5-13

Ravaglioli A, Krajewski A, Celotti GC, Piancastelli A, Bacchini B, Montanari L, Zama G, Piombi L (1996) Mineral evolution of bone. Biomaterials 17:617-622

Sando GN, Rosenbaum LM (1985) Human lysosomal acid lipase cholesteryl ester hydrolase-purification and properties of the form secreted by fibroblasts in microcarrier culture. J Biol Chem 260:5186-5193

Sauerwald T, Skiera D, Kohl CD (2007) Selectivity enhancement of gas sensors using non-equilibrium polarisation effects in metal oxide films. Appl Phys A-Mater 87:525-529

Schultz M (2006) Microscopic structure of bone. In: Haglund WD, Sorg MH (eds) Forensic taphonomy. The postmortem fate of human remains. CRC, Boca Raton, pp 187-200

Schütz S, Weissbecker B, Hummel HE, Apel KH, Schmitz H, Bleckmann H (1999) Insect antenna as a smoke detector. Nature 398:298-299

Sink JD (1979a) Factors influencing the flavour of muscle foods. J Food Sci 44:1-5

Sink JD (1979b) Symposium on meat flavor factors influencing flavor of muscle foods. J Food Sci 44:1-5

Smith KGV (1986) A manual of forensic entomology. Department of Entomology, British Museum (Natural History), London

Smith EA, Macfarlane GT (1996) Enumeration of human colonic bacteria producing phenolic and indolic compounds: effects of $\mathrm{pH}$ carbohydrate availability and retention time on dissimilatory aromatic amino acid metabolism. J Appl Bacteriol 81:288-302

Sos J, Kemeny T, Rigo J, Budavari I (1961) Influence of amino acid deficiency on chemical constitution and solidity of bones. Acta Physiol Hung 19:267

Stahnke LH (1999) Volatiles produced by Staphylococcus xylosus and Staphylococcus carnosus during growth in sausage minces-part II. The influence of growth parameters. Food Sci Technol-LEB 32:365-371

Stams AJM (1994) Metabolic interactions between anaerobic-bacteria in methanogenic environments. Antonie Leeuw Int J G 66:271-294

Statheropoulos M, Spiliopouiou C, Agapiou A (2005) A study of volatile organic compounds evolved from the decaying human body. Forensic Sci Int 153:147-155

Statheropoulos M, Mikedi K, Agapiou A, Georgiadou A, Karma S (2006) Discriminant analysis of volatile organic compounds data related to a new location method of entrapped people in collapsed buildings of an earthquake. Anal Chim Acta 566:207-216

Statheropoulos M, Agapiou A, Spiliopouiou C, Pallis GC, Sianos E (2007) Environmental aspects of VOCs evolved in the early stages of human decomposition. Sci Total Environ 385:221-227

Stensmyr MC, Urru I, Collu I, Celander M, Hansson BS, Angioy AM (2002) Rotting smell of dead-horse arum florets - these blooms chemically fool flies into pollinating them. Nature 420:625-626

Straehlerpohl HJ, Exner M (1985) A comparative-study of the aerobic microorganisms of the oral cavity and nasopharynx cholesteatomas. Arch Oto-Rhino-Laryn 241:120

Stutz HK, Silverman GJ, Angelini P, Levin RE (1991) Bacteria and volatile compounds associated with ground-beef spoilage. J Food Sci 56:1147-1153 
Sunesson AL, Nilsson CA, Andersson B, Blomquist G (1996) Volatile metabolites produced by two fungal species cultivated on building materials. Ann Occup Hyg 40:397-410

Thakeow P, Angeli S, Weissbecker B, Schutz S (2008) Antennal and behavioral responses of Cis boleti to fungal odor of Trametes gibbosa. Chem Senses 33:379-387

Tholl D, Boland W, Hansel A, Loreto F, Rose USR, Schnitzler JP (2006) Practical approaches to plant volatile analysis. Plant J 45:540-560

Toldra F (1998) Proteolysis and lipolysis in flavour development of dry-cured meat products. Meat Sci 49:S101-S110

Vanderzant C, Savell JW, Hanna MO, Potluri V (1986) A comparison of growth of individual meat bacteria on the lean and fatty tissue of beef pork and lamb. J Food Sci 51:5-8

Vanklinken GJ, Hedges REM (1992) Experiments on C-14 dating of contaminated bone using peptides resulting from enzymatic cleavage of collagen. Radiocarbon 34:292-295

Vanklinken GJ, Bowles AD, Hedges REM (1994) Radiocarbon dating of peptides isolated from contaminated fossil bone-collagen by collagenase digestion and reversed-phase chromatography. Geochim Cosmochim Ac 58:2543-2551

Vass AA, Barshick SA, Sega G, Caton J, Skeen JT, Love JC, Synstelien JA (2002) Decomposition chemistry of human remains: a new methodology for determining the postmortem interval. J Forensic Sci 47:542-553

Vass AA, Smith RR, Thompson CV, Burnett MN, Wolf DA, Synstelien JA, Dulgerian N, Eckenrode BA (2004) Decompositional odor analysis database. J Forensic Sci 49:760-769

Vass AA, Smith RR, Thompson CV, Burnett MN, Dulgerian N, Eckenrode BA (2008) Odor analysis of decomposing buried human remains. J Forensic Sci 53:384-391

Vogt RG, Riddiford LM (1981) Pheromone binding and inactivation by moth antennae. Nature 293:161-163
Waksman SA, Starkey RL (1931) The soil and the microbe. Wiley, New York

Weissbecker B, Holighaus G, Schütz S (2004) Gas chromatography with mass spectrometric and electroantennographic detection: analysis of wood odorants by direct coupling of insect olfaction and mass spectrometry. J Chromatogr A 1056:209-216

Wells CL, Maddaus MA, Simmons RL (1988) Proposed mechanisms for the translocation of intestinal bacteria. Rev Infect Dis 10:958 979

Wicher D, Schafer R, Bauernfeind R, Stensmyr MC, Heller R, Heinemann SH, Hansson BS (2008) Drosophila odorant receptors are both ligand-gated and cyclic-nucleotide-activated cation channels. Nature 452:1007-1010

Winquist F, Hornsten EG, Sundgren H, Lundstrom I (1993) Performance of an electronic nose for quality estimation of ground meat. Meas Sci Technol 4:1493-1500

Wolle DD, Banavara DS, Rankin SA (2006) Short communication: empirical and mechanistic evidence for the role of pyridoxal-5'phosphate in the generation of methanethiol from methionine. $J$ Dairy Sci 89:4545-4550

Yan F, Mcnally R, Kontanis EJ, Sadik OA (2001) Preliminary quantitative investigation of postmortem adipocere formation. J Forensic Sci 46:609-614

Yeung DKW, Lam SL, Griffith JF, Chan ABW, Chen ZY, Tsang PH, Leung PC (2008) Analysis of bone marrow fatty acid composition using high-resolution proton NMR spectroscopy. Chem Phys Lipids 151:103-109

Young LY, Rivera MD (1985) Methanogenic degradation of 4 phenolic-compounds. Water Res 19:1325-1332

Zhang CH, Hirano T, Suzuki T, Shirai T (1992) Studies on the odor of fishes. 2. Enzymatically generated specific volatile compounds in ayu tissues. Nippon Suisan Gakk 58:559-565 